University of Tennessee, Knoxville

From the SelectedWorks of Asafa Jalata

Winter May 23, 2011

European Colonial Terrorism and the Incorporation of Africa into the Capitalist World System

Asafa Jalata, University of Tennessee - Knoxville 


\title{
COLONIAL TERRORISM AND THE INCORPORATION OF AFRICA INTO THE CAPITALIST WORLD SYSTEM
}

\author{
Asafa Jalata \\ Professor of Sociology, Global Studies and Africana Studies, and Interim \\ Chair of the Africana Studies Program at the University of \\ Tennessee, Knoxville
}

\begin{abstract}
This article critically explores the essence and characters of European colonial terrorism and its main consequences on various African peoples during racial slavery, colonization, and incorporation into the European-dominated capitalist world system between the late $15^{\text {th }}$ and $20^{\text {th }}$ centuries. It employs multidimensional, comparative methods, and critical approaches to explain the dynamic interplay among social structures, human agency, and terrorism to critically understand the connections among terrorism, the emergence of globalization, and African underdevelopment. The piece focuses on four central issues: First, it conceptualizes and theorizes terrorism to clarify its roles in creating and maintaining the global system. Second, it focuses on the first wave of European colonial terrorism that was practiced via racial slavery by focusing on the dialectical connections among various forms of violence and genocide to demonstrate the process of enslaving and merchandising Africans. Third, the chapter deals with the second wave of European colonial terrorism by focusing on the process of colonizing of the whole continent by violently destroying African peoples and their institutions to enrich European colonialists and their African collaborators and their governments and companies.
\end{abstract}




\section{European Colonial Terrorism and its Impacts on Africa}

For almost five centuries, European empire builders, namely Portugal, Holland, France, England, Belgium, Germany, Italy, and Spain employed different strategies and tactics in Africa to make money through the ownership of human beings, exploration, evangelization, colonization, commercialization, banditry, robbery, and theft. The processes of merchandizing some Africans, dominating and controlling of trade, destroying African cultures and religions, imposing Christianity, destroying African leadership and sovereignties through establishing colonial governments, and dispossessing lands and other economic resources, and transforming Africans into coerced laborers involved war and terrorism. To use different forms of violence in merchandising Africans and taking over the homelands and resources of the indigenous peoples is an act of terrorism. Terrorism and other forms of violence enabled these empire builders to enrich themselves and their collaborators at the cost of Africans; consequently, they established themselves as powerful countries, claimed racial superiority, and imposed their cultures and Christian religion on Africans.

Although several scholars have explored the impacts of slavery, exploration, Christianity, and colonization on the entire continent, they have ignored to study the essence and role of European terrorism in the destruction and dehumanization of African societies and in the establishment and maintenance of the European dominated racialized capitalist world system. ${ }^{1}$ Despite the fact that these European powers and their agents used the discourses of commerce, Christianity, modernity, and civilization to cultivate their African collaborators for dividing and conquering Africa, systematic terrorism and other forms of violence enabled them to dominate African societies and exploit their economic and labor resources beginning in the late $15^{\text {th }}$ century and reaching its climax during the last decades of the $19^{\text {th }}$ century. "Everywhere the conquests of Africa brought similar paradoxes of public disaster and private profit in their train," John Lonsdale $(1985,722)$ notes, "confusions of established orders which colonial rulers had everywhere in some fashion to put back to rights."

The slave system and colonial orders were established and maintained mainly through terrorism. European countries and others that involved in Africa try to forget the deaths and suffering caused by racial slavery, the blood spilled, mass murders and genocide, the severed hands and heads, the shattered families, and other crimes committed in Africa to extract wealth and capital. As Adam Hochschild $(1998,295)$ notes, "Forgetting one's participation in mass murder is not something passive; it is an active deed. In looking at the memories recorded by the early white conquistadors in Africa, we can sometimes catch the act of forgetting at the very moment it happens." When various African peoples intensified their respective resistance to racial slavery, colonial expansion, domination, and exploitation and later engaged in national liberation struggles in the $20^{\text {th }}$ century, some of these empire builders increased their levels of terrorism to prevent the reemergence of African sovereignties and to continue their theft and robbery of African resources. Jean Ganiage

\footnotetext{
${ }^{1}$ For instance, see Bill Freund, The Making of Contemporary Africa, (Bloomington, Indiana University Press, 1984); Immanuel Wallerstein, "The Three-Stages of African Involvement in the World-Economy," Political Economy of Contemporary Africa, edited by Peter C. W. Gutkind and Immanuel Wallerstein, second edition, (London: Sage Publications, 1985), pp. 35-63
}

[Type text] 
(1985, 157) asserts that European policy makers planned and acted "to crush African resistance by a ruthlessly systematic exploitation of the technological gap between European and African weaponry and military organization."

The "war of any sort is not much more than 'a series of errors and accidents' . . Its annals have more to tell us of man's nature than anything else. Those colonial wars, in particular, leave us to wonder whether the conqueror's violence has been an authentic expression of human nature, or a derangement of it" (V.G. Kiernan (1982, 230). Whatever human nature is the European colonial powers engaged in all forms of violence to make blood money and enrich themselves by merchandizing human beings, committing mass murders and genocide, and engaging in theft and robbery. Africans were exposed to two waves of terror: The first wave started in the late $15^{\text {th }}$ century with merchandising some Africans at gunpoint and colonizing some limited coastal islands or territories (about 10 percent of Africa). The second wave emerged in the first half of the $19^{\text {th }}$ century and consolidated with the partition and colonization of the remaining 90 percent of the continent in the late $19^{\text {th }}$ century. ${ }^{2}$ For the sake of clarity and a better understanding of terrorism, it is necessary to define and theorize it in relation to the capitalist world system.

\section{Toward Defining and Theorizing Terrorism}

Considering the historical and global context in which terrorism emerged and intensified, we need a more comprehensive and broader definition of terrorism. So, I define terrorism as a systematic governmental or organizational policy through which lethal violence is practiced openly or covertly to impose terror on a given population group and their institutions or symbols or their representative members to change their behavior of political resistance to domination or their behavior of domination for political and economic gains or other reasons. Both state and non-state actors use terrorism; the former has used it to maintain state power or to loot resources and the latter mostly to resist the oppressive and exploitative policies of states. There are also non-state terrorist agencies that advance extremist religious and racist ideologies and practices on a sub-national or international level. According to John W. Sloan (1984: 84), "Since governmental groups have the resources of the state at their disposal, they are usually capable of engaging in higher levels of terrorism than the guerrillas."

However, transnational terrorist organizations such as Al Qaeda have adequate human, financial, and intellectual resources to impose horrifying terrorist activities on targeted audiences on a global level. All forms of terrorists though attempt to hide the lethal consequences of terrorism and their crimes against humanity by discoursing over civilization, progress, democracy, national liberation or religious rights. Most people are easily persuaded by such discourses and take sides without understanding or ignoring the consequences. Unfortunately, the terrorism that powerless or colonized peoples experience receives inadequate attention while terrorism that is visited upon powerful groups or nations receives

\footnotetext{
${ }^{2}$ Before the Scramble for Africa in the 1880 s "very little of Africa was under colonial rule-less than 10 percent, consisting of small areas along the coast where trade was carried out. The greater part of the African interior was unknown to Europeans. The few colonies of the British included areas around Freetown in Sierra Leone, forts in the Gambia, Lagos, a protectorate in the southern Gold Coast (now Ghana), and some areas in South Africa. The French had control in St. Louis and Dakar in Senegal, Grand Bassam and Assini in Côte d'Ivoire, and a small coastal area in Dahomey (now the Republic of Benin). The Portuguese were established in [the coastal areas of] Mozambique and Angola" (Falola 2002, 175).
}

[Type text] 
more attention and publicity. Some states and powerful peoples do not recognize that all human groups have the right to life and liberty and should be protected from all forms terrorism. We know that human beings, since time immemorial, have been known to engage in violence over resources, religion, and territories. ${ }^{3}$

There have also been human groups that have engaged in peaceful co-existence and cooperation and have shared their available resources. History demonstrates that some individuals or groups have also engaged in conflict and war over economic interests such as land, water, and commerce (Black 2004: 23). The intensity and danger of terrorism and genocide have increased with the advancement of technology-first with gun making and subsequently with the production of other powerful weapons. According to Paul Wilkinson (1979: 45), "We really understand very little about the origins and causes of human violence in all its daunting variety. . . There is no substantial theoretical literature in social science concerned specifically with terrorist phenomena." Nevertheless, since the frequency, intensity, and the volume of terrorism have increased with the emergence and development of global capitalism, a definition and a theory of terrorism cannot be adequately developed without considering terrorism as an aspect of the racialized capitalist world system. Beginning in 1492, European colonialists engaged in terrorism, genocide, and enforced servitude in the Americas and extended their violence into Africa through racial slavery. Then, in the nineteenth century, they incorporated other parts of the world into this system through colonial terrorism and genocidal wars.

Most scholars have avoided providing a comprehensive and critical analysis and an objective definition and theorization of this aspect of the modern world system. Even those critical scholars like Karl Marx, ${ }^{4}$ Andre Gunder Frank, ${ }^{5}$ Immanuel Wallerstein, ${ }^{6}$ and others who have studied the emergence, development, and expansion of the racialized capitalist world system have primarily focused on trade, the international division of labor, exploitation, capital accumulation, political structures, development and underdevelopment, and social inequality and have ignored the role of terrorism in creating and maintaining the system. Such critical scholars have not provided an adequate explanation of the role of state-

\footnotetext{
${ }^{3}$ Paul Wilkinson (1979: 46) raises essential questions when he asks, "Why is man the only species that indulges in interspecies violence on a really massive and disruptive scale? Why does man alone among all creatures commit acts of mass murder and promiscuous cruelty and sadism? Under what conditions and for what reasons do men resort to one form of violence rather than another? And why is that, faced with similar threats, conditions, circumstances, or pressures, some individuals reacting violently when others do not?"

${ }^{4}$ It was Karl Marx who started the study of the emergence and development of capitalism as the modern world system. Although he did not adequately explain the consequences of terrorism and genocide on the indigenous peoples of the Americas, Asia, and Africa, he briefly mentioned the devastating effects of colonial capitalism on these peoples. According to Marx (1967: 753-754), "The colonies secured a market for the budding manufactures, and, through the monopoly of the market, an increasing accumulation. The treasures captured outside Europe by undisguised looting, enslavement, and murder, floated back to the mother country and were turned into capital. . . . As a matter of fact, the methods of primitive accumulation are anything but idyllic. . . . In actual history it is notorious that conquest, enslavement, robbery, murder, briefly force, plays the great part. . . . In fact, the veiled slavery of the wage workers in Europe needed, for its pedestal, slavery pure and simple in the new world. . . . Capital comes [into the world] dripping from head to foot, from every pore, with blood and dirt."

${ }^{5}$ See Frank $(1778,1979)$ for global accumulation of capital between 1492 and 1789.

${ }^{6}$ Immanuel Wallerstein also wrote several books and articles to explain how capitalism became the global system. Despite this, he too has inadequately explained the role of terrorism in creating and maintaining the capitalist world system. See for example, Wallerstein, (1974; 1980).
}

[Type text] 
centered or state-sponsored terrorism in destroying or enslaving the indigenous peoples of the world and in creating, developing, and maintaining the racialized capitalist world system. Although Marx recognized the cruelty and consequences of the capitalist world system, he did not explore the idea that terrorism was an integral part of the broadening of the system. Marx focused on capitalist development in Europe and indirectly studied its relations to colonized societies.

Other critical scholars have also followed his Euro-centric paradigm. We learn from history that political violence has increased as different societies engaged in improved techniques of production, produced surplus wealth, developed their organizational capacity, and improved their technological innovations. The emergence of the nation-state with the development of capitalism in the $16^{\text {th }}$ century in Europe created the organizational and technological capacity to engage in more lethal violence and war. In England, France, Italy, Spain, Portugal, and the Netherlands, the $16^{\text {th }}$ century was the period of the formation of the nation-state (Frank 1978: 51-52). Capitalism had "witnessed the first long, sustained, and widespread quantitative and qualitative development . . . in its mercantile stage and the first period of concentrated capital accumulation in Europe" (Frank 1978: 52). As competition increased among individuals, groups, and states over scarce and valued resources, political violence, terrorism, and war increased. The West and their collaborators used the ideologies of racism ${ }^{7}$ and religious absolutism to justify colonial terrorism, war, slavery, and genocide. Although "ideologies [as] qua abstract doctrine do not in themselves directly cause violence, ideological movements, which define enemies and incite to combat, do frequently instigate political violence, wars, and "crusades"” (Wilkinson 1979: 62).

As capitalism developed in Western Europe, the need for raw materials, minerals such as gold and silver, markets, and free or cheap labor expanded due to the desire to minimize the cost of production and to increase the accumulation of capital or wealth. This need was fulfilled through terrorism and genocide. "The treasures captured outside of Europe by undisguised looting, enslavement, and murder," Karl Marx (1967: 753-754) writes, "floated back to the mother-country and were there turned to capital." Most liberal and leftist scholars have failed to identify and explain the role of state-sponsored or state terrorism that colonial officials, European companies, and expeditionary forces used during the expansion of the racialized capitalist world system to transfer economic resources of the indigenous peoples to European colonial forces or settlers, or their collaborators. Under the guises of "free markets," "civilization," and Christianity, forces of European states or state-sponsored companies committed acts of terrorism and genocide that were, more or less, ignored. In fact, the issue of terrorism only started to be addressed when, after WWI, colonized peoples began their liberation struggles against European colonial states.

The terrorist attack on the life and liberty of indigenous peoples by European colonial powers and their collaborators destroyed existing institutions and economies and exposed the

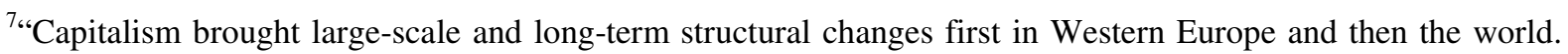
The process of expropriation, slavery, and colonialism resulted in hierarchical organization of world populations through the creation of an elaborate discourse of racism to maintain the system. It is essential to provide a pragmatic definition of racism. . . As the meaning of race is complex, so is that of racism. Racism is a discourse and a practice in which a racial/ethnonational project is politically, culturally, and 'scientifically' constructed by global and regional elites in the capitalist world system to naturalize and justify racial/ethnonational inequality in which those at the top of the hierarchy oppress and exploit those below them by claiming biological and/or cultural superiority" (Jalata 2001:8).
}

[Type text] 
conquered peoples to poverty and famine-induced "holocausts" (Davis 2001). Discussing how the cultural destruction of indigenous peoples resulted in massive deaths, Polanyi (1944: 159-160) argues, "The catastrophe of the native community is a direct result of the rapid and violent disruption of the basic institutions of the victim. . These institutions are disrupted by the very fact that a market economy is foisted upon an entirely differently organized community; labor and land are made into a commodity, which, again, is only a short formula for the liquidation of every . . cultural institution in an organic society." The capitalist world economy that, in the $19^{\text {th }}$ century, was permanently eliminating famine from Western Europe was at the same time accelerating famine and famine-induced deaths in the rest of the world: "Millions died, not outside the 'modern world system,' but in the very process of being forcibly incorporated into its economic and political structures. They died in the golden age of Liberal Capitalism; indeed, many were murdered . . . by the theological application of the sacred principles of [Adam] Smith" (Davis 2001: 9).

As previously mentioned, most commentators and scholars have focused on the oppositional terrorism of various organizations or movements in the West and national liberation movements in the periphery of the world. ${ }^{8}$ In the names of "free markets," economic liberalization, the promotion of democracy, and a global war against terrorism, Western powers and some states in the Rest still engage in terrorism and hidden genocide to implement their draconian economic and political policies. "The war on terrorism is being used as a continuation of the war on social justice. . . [it is a war] waged with the economic weapons of the international financial institutions" (Eisenstein 2001: 136). Western powers, multinational corporations, and state elites in the Rest have collaborated and engaged in massive human rights violations and terrorism ${ }^{9}$ even as Western-based human right organizations have systematically exposed such crimes. Bushnell and colleagues (1991: 11) identify four conditions that are associated with the development of state terrorism. They include: "(1) distorted conceptions of the state and society and their inter-relationship, (2) the disarray of state institutions, (3) the presence of deep economic and/or ethnic conflicts in society or between the society and the state, and (4) state dependence on foreign power."

\footnotetext{
${ }^{8}$ National liberation movements that have fought against colonialism and racism have been labeled terrorist whether or not they used terrorist tactics. For instance, the Algerian National Liberation Front (1954-1962), the Palestine Liberation Organization (1964-present) and other Palestinian liberation organizations (such as the Popular Front for the Liberation of Palestine, Hamas and the Palestinian Islamic Jihad), the Liberation Tigers of Tamil Eelam in Sri Lanka (1983-present) [it was defeated recently], the African National Congress in South Africa (1961-1990), the Basque Homeland and Freedom in Spain (1968-present), the Irish Republican Army (1969-1997), and Chechen Separatists (1996-present) have been labeled as terrorist organizations since they used "limited selective terrorism" (Goodwin 2006, 2032) in their respective national struggles. Other political organizations, like the Sandinista National Liberation Front (1961-1979) in Nicaragua, the Farabundo Marti Front for National Liberation in El Salvador (1980-1992) and others were also labeled as terrorists by states and their international collaborators for using "limited selective terrorism." Most scholars and state elites in the capitalist world system believe that since the state has the monopoly of violence its violent activities are not terrorism.

${ }^{9}$ See the film narrated by Robert Richter, Hungry for Profit, 1990 (New Day Film library, 22 D Hollywood Ave., Ho-Ho-Kus, NJ 07423). In this film Richter explains how transnational corporations in agribusiness work with Third World governments and international banks, international agencies, foundations, and the World Bank to engage in terrorizing and evicting or forcing peasants to sell their lands at gunpoint in Latin America, Asia, and Africa. These Third World governments use military and paramilitary forces to implement these draconian economic policies through state terrorism. Sometimes those who lose their lands engage in revolutionary or peaceful resistance to regain their lands, liberty and life.
}

[Type text] 
In the capitalist world system, political institutions such as nation-states, multinational corporations, and international organizations allow the practices of state organized terror since it does not directly affect their interests. In theorizing non-state terrorism, scholars such as Roberta Senechal de la Roche (1996) assert that the accumulation of grievances causes terrorism and "social polarization" between socially and culturally distant groups. Long standing collective grievances and the right social geometry, such as a higher degree of cultural and religious differences, relational distance, and social inequality between the aggrieved and the dominant population groups can sometimes contribute to the development of non-state terrorism ${ }^{10}$ (see Black 2004). Jeff Godwin (2006: 2038) advances a theory of categorical terrorism: "The main strategic objective - the primary incentive - of categorical terrorism is to induce complicitous civilians to support, or to proactively demand changes in, certain government policies or the government itself. Categorical terrorism, in other words, mainly aims to apply such intense pressure to complicitous civilians that they will demand that 'their' government change or abandon policies that the revolutionaries oppose." Using this theory, Godwin concludes that Al Qeada attacked the United States on September 11, 2001, because they considered Americans to be "complicitous citizens" who support the foreign policy of the US country in the Middle East. ${ }^{11}$

As states engage in terrorist activities to promote their economic and political domination, non-state terrorist agencies use similar techniques to oppose and challenge such policies, behavior, and practices. Therefore, without making governments that engage in state terrorism directly or indirectly accountable and without understanding and dealing with the root problems of terrorism, we cannot deal with a branch of terrorism-non-state terrorism. Whether terrorism is committed by states or non-states, it affects noncombatant civilians. As a crime against humanity, it is a dark side of human civilization. Hence, it is urgent that serious scholars establish a single moral, intellectual, legal, and political position in the study and understanding of all forms of terrorism and suggest pragmatic policies to reduce or eliminate the problem of terrorism. This piece examines the essence and consequences of European colonial terrorism that was sponsored by various European colonial states in engaging racial slavery and colonialism in Africa.

\section{The first Wave of Terror: Owning and Merchandising Africans}

The practices of attacking, raiding, capturing, and owning human beings, as well as the dispossessing of the lands of African peoples involved colonial terrorism. The slavers and

\footnotetext{
${ }^{10}$ For some scholars, weak and desperate groups that lack popular support to redress what they consider grievances engage in terrorism. For instance, according to Crenshaw (1981: 384), "Terrorism is the resort of an elite when conditions are not revolutionary ... terrorism is most likely to occur precisely where mass passivity and elite dissatisfaction coincide."

${ }^{11}$ Similarly, Ward Churchill (2003) severely criticizes the American people for not preventing US policies and actions that have caused massive human rights violations around the world; he also asserts that claiming "innocence" or ignorance of the facts cannot absolve them from being accountable for the government that they put in power through election. Faith Attaguile (2004: 3) also suggests that "until we take responsibility for terrorism perpetrated in our name, and until we end that terror, we can't stop the terror returned." Although the American people have a moral and political responsibility to make their government accountable, the failure to do this cannot justify terrorist attacks on them. Churchill explains why those who push back against unfair US policies sometimes decide to engage in terrorism have twisted minds: "whoever they might otherwise have been or become the sheer and unrelenting brutality of the circumstances compelling their response is all but guaranteed to have twisted and deformed their outlooks in some truly hideous ways" (p. 10).
}

[Type text] 
colonizers also used various forms of violence to force people to forsake their individual and group sovereignties in order to use them as commodities and to exploit their labor and economic resources. Enslaving some Africans involved warfare, trickery, banditry, kidnapping, burning villages, raping, torturing, dividing and destroying communities, facilitating civil war, and destroying existing leaderships and institutions and cultures; such forms of social violence can be categorized as terrorism. ${ }^{12}$ Between 13 million and 15 million Africans were merchandized as commodities by European slave traders and their African collaborators and transported to the Americas. ${ }^{13}$ There were also Africans who were enslaved by Arabs and their African collaborators and exported to Asia. Furthermore, millions of Africans were also merchandized and worked on European plantations, farms, and mining in Africa; some of them worked as domestic workers and porters. Slavery caused the emergence of African Diaspora communities in the Americas and Europe; today the majority of them face the problem of underdevelopment in the rich belly of Western societies as their brothers and sisters are in Africa. ${ }^{14}$

Some European powers committed crimes against humanity for almost five centuries on most Africans. How did all these happen? The development of mercantilism in Western Europe in the late $15^{\text {th }}$ century enabled some European countries to have technological knowledge to build ships and cannons and to navigate seaways and gradually establish control overall the world's sea ways such as the North Sea, the Atlantic, Pacific and Indian oceans, and the Mediterranean Sea. Consequently, some European powers started to own seagoing vessels and cannons and to finance the exploration of the unknown continents. ${ }^{15}$ The Portuguese empire builders came first to Africa and left last. ${ }^{16}$ Portugal started to stage

\footnotetext{
${ }^{12} \mathrm{I}$ do not think that we can adequately explain how the terrorism of slavery affected enslaved Africans. According to Toyin Falola (2002: 116), "The experience of slavery was one of human suffering that is hard to describe. The wars that produced the captives sold into slavery were traumatizing. Then came the Middle Passage-when the slaves were transported across the sea. Stripped, dehumanized, and branded, they were packed into small spaces and fed contaminated food and water. Dysentery, smallpox, and measles were among the diseases that afflicted a huge number. Many did not make it-one out of six never survived the journey. Those who made it arrived 'looking like skeletons' ... [T] [Tey were 'completely naked, and are shut up in a large court or enclosure . . f for as a rule are left to lie on the ground, naked without shelter.' Buyers examined and auctioned them like cattle. Then came the experience on the plantations where they were treated as property, regarded as no better than cattle."

${ }^{13}$ Toyin Falola $(2002,11)$ estimated that over 13 millions Africans were enslaved. However, Baisl Davidson (1984) estimated around 15 million in his film "Africa: The Bible and the Gun."

${ }^{14}$ For example, see Manning Marable, How Capitalism Underdeveloped Black America, (Boston: South End Press, 1983).

${ }^{15}$ For example, Portugal financed the expedition of Bartholomew Dias that rounded the Cape peninsula in 1487, anchored in Mossel Bay, and traveled to the coast of Angola. It also financed the voyage of Vasco da Gama that rounded and explored the Cape of Good Hope in 1497-98, sailed along the east African coastline to Malindi (modern Mombasa), crossed the Indian Ocean to Calcutta, India, and returned to Portugal after twentysix months. Similarly, Spain financed the four voyages of Christopher Columbus to the Americas between 14923, 1493-6, 1498-1500, and 1502-04. The crossing of the Atlantic Ocean in 1492 by Christopher Columbus and the crossing of the Indian Ocean in 1497 by Vasco da Gama "Changed the course of both Western and Eastern history" (Boorstin, 1983, 177). Spain financed the former and Portugal the latter. Gradually some European countries gained a monopoly of information and knowledge in international trade among Europe, the Americas, Africa, and Asia (Rodney 1972). It was Portugal that started to engage in various forms of violence to enslave and colonize Africans.

${ }^{16}$ Portugal was interested in Africa for four major reasons. The first reason was to exploit African economic and human and labor resources. The second reason was to obtain African labor to exploit Brazil and its African island colonies. The third reason was to dominate commerce on the Atlantic and Indian oceans and between the [Type text]
} 
colonial expansion to overcome the problem of food deficit and seek overseas' wealth; the technology of ship building and the availability of guns enabled the Portuguese first to colonize the islands of Azores and Madeira to cultivate wheat by using the labor of European migrants driven by hunger and captured slaves raided from the African coast (Birmingham 1999, 2). The Portuguese colonialists also captured and settled the Canary Islands, the offshore islands of Morocco, and occupied the Morocco fortress of Ceuta in the $15^{\text {th }}$ century. After controlling the Atlantic Coast of Morocco, the Portuguese colonized some parts of African coast, established sugar plantations on the islands, and built trade factories on the beaches. $^{17}$

Portuguese ambitions in Africa were diffuse during the $16^{\text {th }}$ and $17^{\text {th }}$ centuries: "One was to secure manpower to exploit in Brazil and the island colonies, but the Portuguese state and Portuguese merchants were equally interested in the spice trade, in precious metals, particularly gold, and in forging strategic alliance aimed against Mameluk Egypt and then the Ottoman Empire" (Freund 1984, 40). To satisfy the needs of labor and commerce and to collect information on Africa, raiding, capturing, and owing Africans became an important enterprise for the Portuguese. ${ }^{18}$ Realizing the profitability of the slave trade, those merchants who were not convinced about the profitability slavery changed their mind: "The outcome of their talking was financial support for a large expedition of six ships . . . and a small scale war on the western coast in which one hundred and sixty-five men, women, and children were taken captives 'besides those that perished and were killed"' (Basil 1961, 37).

Slave merchants started to send expeditions to import more and more slaves to Europe and the Americas. The Portuguese through "a diplomatic mission of friendship and alliance" with the agreement of the leaders of the people built their first fort called Elmina ("the mine") on the coast of Gold Coast (now Ghana) in 1481 to get access to African slaves and gold. ${ }^{19}$

West and Asia. The fourth reason was to create alliance with some African rulers against the Ottoman Empire (see Rodney 1972). Portugal engaged in several oversea explorations to achieve these objectives. It initiated explorations "due primarily to the superb shelter which the harbour of Lisbon provided to mariners on otherwise inhospitable coast of south-eastern Europe" (Birmingham 1991, 1). According to David Birmingham (1991, 2), "The rise of Lisbon as the maritime gateway between northern and southern Europe led to the growth of an urban middle class with merchant and banking skills learnt from Italy. It was this middle class, which became the driving force behind the Portuguese search for new wealth overseas. It found its patron in the royal prince, Pedro, brother of the vaunted Henry the Navigator."

${ }^{17}$ David Birmingham (1999, vii) notes that "until in 1488 one of the sea-captains, Bartholomew Dias, reached Africa's furthest shore at the Cape of Good Hope. For the next 10 years Portugal concentrated on buying gold in West Africa and establishing missionary bridgehead in the kingdom of Kongo [sic], but in 1498 another seacaptain, Vasco da Gama, rounded the tip of South Africa and opened direct communication between Europe and the city states of the East African coast."

${ }^{18}$ Antam Conçalvez with his nine-crew sailed on the Atlantic coast of Africa in 1441 and captured one African man and one African woman to collect information on Africa and its peoples (Davidson 1961, 33-34). According to Basil Davidson (1961, 34-35), "This need for information merged in Europe, as in Africa, with the commercial and social advantages of capturing people who could be sold as slaves." Nun̆o Tristăo, another Portuguese slaver was also on the coast and joined Conçalvez to engage in slave raiding. These Portuguese attacked a few Africans and took twelve African captives to Lisbon (Basil, 1961, 35). "In 1443-1444 Nuňo Tristăo ... reached the island of Arguim, soon to become famous in Portuguese slaving annuals, and seized twenty-nine men and women from canoes in which they were padding near the shore" (Basil 1961, 36).

${ }^{19}$ The Portuguese used slavery, commerce, and colonialism to dominate and exploit the African coast. According to Arslan Humbaraci and Nicole Muchnik (1974, 85), "The history of Portuguese colonialism in Africa stretches from 1445 right up to [the mid-1970s], and it is in many ways a classic example of its kind. The Portuguese were the first to approach the unexplored continent, by way of the Cape Verde Islands. In the [Type text] 
The Portuguese forces had merchandized some Africans to use them on their plantations both in Africa ${ }^{20}$ and Brazil. The slave labor helped Portugal to experiment her colonial practices on the Atlantic and the Cape Verde islands, which became known for textile industry. Furthermore, the Portuguese merchants developed a colonial plantation economy on the Atlantic coast of Africa: "The tropical island of São Tomé, off the Niger delta, proved to have excellent soil and plentiful rainfall. The merchant community of Lisbon . . . especially its Jewish economic pioneers, experimented with the introduction of sugar cane" (Birmingham 1999, 5). Later, other European powers learned from the experiment.

Portugal also extended its imperialist and trade influence on the East African coast in the $16^{\text {th }}$ century and involved in what is today Kenya, Tanzania, and Abyssinia (now Ethiopia) as part of its broader Indian Ocean strategy (Freund 1985, 41). It forced the Swahili coastal towns to submit or form alliance. Portuguese expeditions also engaged in sacking and plundering African cities. ${ }^{21}$ Although it was not successfully, Portugal attempted to impose Catholicism on ruling houses and mobilizing them against Muslim empire builders. ${ }^{22}$ The Portuguese also established her sphere of influence in the Zambesi valley, Zimbabwe, and the Congo. They also created permanent settlements in Angola and Mozambique. Gradually the Portuguese colonies included Angola, the islands of São Tomé and Príncipe, Guinea Bissau, Cape Verde Islands, and Mozambique. Portugal founded Luanda, the capital of Angola, in 1575; it was the oldest European colonial settlement in the south of the equator.

Although salt, iron, copper, ivory, and gold attracted the Portuguese to Africa, "slaves were always more important than [other commodities] in the mobile zones of frontier exploitation that were opened up by ocean navigation in the Atlantic" (Birmingham 1999, 17). Inter-European competition for slaves to man their mines and plantations of the Americas intensified slavery in Africa. England, France, Holland, and Spain also participated in the Atlantic slave trade for more than three centuries. These European powers with their African collaborators terrorized and dehumanized some Africans they were enslaving. "Where warfare and violence stimulated the initial capture," Joseph C. Miller (2002, 45), notes, "the victims would have begun their odysseys in exhausted, shaken, and perhaps

fifteenth century, Portugal was at the height of her power, and at the instigation of Henry the Navigator she began a systematic exploration of the African continent. The original aim was merely to establish trading posts on the rote to the Indies. Africa was no more than an obligatory staging-point on this route. But with the beginnings of the slave trade . . the trading posts, and Africa itself, became of major importance."

${ }^{20}$ They invested in the Canary Islands to establish the wine industry. Using its vessels and cannons, they started to engage in raiding and owning Africans to use them as free labor. They also purchased slaves from African slave hunters who collaborated with Europeans in merchandizing their own people. Portuguese ships reached the Cape Verde Islands in 1460, the Gulf Guinea in 1449, and the islands of Săo Tomé and príncipe in 1449, the mouth of the Congo in 1490.

${ }^{21}$ For instance, in 1505 d'Almedia's expedition captured, looted, and burned Kilawa, the wealthiest city, and Mombasa in east Africa. After occupying Kilwa, "the Vicar-General and some of the Franciscan fathers came ashore carrying two crosses in procession and singing the Tem Deum. They went to the palace, and there the cross was put down and the Grand-Captain prayed. Then everyone started to plunder the town of all its merchandise and provisions. Two days later d'Almeida fired the town, destroying . . . [and calling it] 'the greater part of this city of abomination"” (Davidson 1991, 164).

${ }^{22}$ Portugal allied with Abyssinian/Ethiopian rulers to mobilize them against Egypt and Turkey. When an Islamic force defeated Christian Abyssinia in the $16^{\text {th }}$ century, "Vasco da Gama's grandson and several hundred Portuguese soldiers were dispatched and proved crucial in turning the tide against Ahmed Gran̆, ${ }^{22}$ who was killed in battle with a new Christian ruler in 1543" (Freund 1984, 42). The Portuguese kept their soldiers in Abyssinia for almost a century.

[Type text] 
wounded physical condition." Since raiding, capturing, merchandising human beings, and transporting them involved several lethal dangers, a great portion of the enslaved Africans perished. ${ }^{23}$ As Henry W. Nevinson $(1906,113)$ writes, “The path is strewn with dead men's [and women's] bones. You see the white thighbones lying in front of your feet, and at one side, among the undergrowth, you find the skull. These are the skeletons of slaves who have been unable to keep up with the march, and so were murdered or left to die."

Those enslaved Africans who survived the danger of death were dehumanized and treated like animals: "The great majority of the slaves went directly to the slave pens . . . These barracoons ... a a word also applied to farmyards for keeping animals-were usually barren enclosures ... Large numbers of slaves accumulated within these pens, living for days and weeks surrounded by walls too high for a person to scale, squatting helplessly, naked, on the dirt and entirely exposed to the skies except for a few adjoining cells where they could be locked at night. They lived in a 'wormy morass' . . . and slept in their own excrement, without even a bonfire for warmth" (Mills 2002, 49). The European powers also needed enslaved labor to develop their colonies in Africa. As Birmingham (1999, 10) asserts, "Slavery was accepted as the normal means to acquire labour both in the artisan shops of the city and on the farms. White women were rare among the settlers and concubines of every race were readily accepted and acknowledged as they had been on the old colonial estates." Realizing the inhumanity and barbarism of these Europeans, enslaved Africans were even terrorized by seeing them: "All slaves trembled in terror at meeting the white cannibals of the cities, the first Europeans whom many of the slaves would have seen. They feared the whites' intention of converting African brains' into cheese or rendering the fat of African bodies into cooking oil, as well as burning their bones into gunpowder"(Miller 2002, 49).

The European powers used various forms of violence, predominantly terrorism, to acquire free or cheap labor and to invade and take over African lands and others resources while claiming that they were promoting Christianity, civilization, and modernity. For instance, the Portuguese engaged in series of wars and terrorism that resulted in bloodbath and the devastation of African communities. According to Arslan Humbaraci and Nicole Muchnik (1974, 88), "Angola was the first region to be subjected to the hordes of slave traders ... Since it faced the Atlantic, Angola was a more obvious choice than Mozambique for the navigators leaving for the New World. . . . Thus it was Angola, which paid the heaviest price - in three hundred years four million Angolans were unloaded from the slave ships on to the shores of the Americas. To this number must be added the proportion that were shipwrecked or died during the crossing - in some cases as many as 80 per cent." Let us turn now to the second wave of European colonial terrorism.

\section{The Second Wave of Colonial Terrorism}

The second phase of colonial terrorism started in the first half of the $19^{\text {th }}$ century and intensified in the last decades of the same century. Between 1830 and 1845, the French army engaged in terrorism, killing men, women, an children, and annihilating some clan families, beheading their leaders, setting fires, "smoking ... men, women and children to death," and throwing hundreds of corpses in caves (Kiernan 2007, 365). The practices of French terrorism in Algeria also included seizing flocks and herds, looting granaries, destroying

\footnotetext{
${ }^{23}$ Some African commercial and political elites also participated in enslaving their African brothers and sisters and contributed in the destruction of some African communities and peoples (Thornton 2002, 63).
}

[Type text] 
crops and orchards, killing leaders, and burning villages and cities (Vandervort 1998, 68). V. G. Kiernan $(1982,163)$ asserts that "the worst in the conquest of Algeria occurred in 1845 and made a great stir at the time. A force led by Pélissier trapped some five hundred men, women and children in the Dahra caves, and kept fires burning at the entrance until they were all suffocated." The French military leaders in Algeria "ordered summary executions on the slightest suspicion, [and] showed 'unnecessary cruelty"” (V. G. Kiernan 1982, 73).

Within the first three decades, the French military massacred between 500,000 to 1 million from approximately 3 million Algerian people (Kiernan 2007, 364-365). According to Ben Kiernan (2007, 374), "By 1875, the French conquest was complete. The war had killed approximately 825,000 indigenous Algerians since 1830. A long shadow of genocidal hatred persisted, provoking a French author to protest in 1882 that in Algeria, "we hear it repeated every day that we must expel the native and if necessary destroy them." The French burned the city of Constantine; 20,000 French troops "bombarded and attacked the town of 30,000 , leaving corpses of the inhabitants strewn 'everywhere on the ground.' 'The threshold, the courtyard, the stairs, the apartments, all these places were covered with bodies so close together that it was difficult to take a step without treading on them. And what to say of this trail of bodies on the torturous contour of the precipice where the unfortunate women had tumbled with their children on being seized with fright at our entry into the town'" (Kiernan 2007, 368-369). All these crimes against humanity were committed to cow the Algerian population.

Some lands of Algerians were expropriated and given to French settlers. The French settlers reached 4,000 families in 1882, and the colonial government established 197 settlements by granting lands freely totaling 347,000 hectares (Ganiage 1985, 163). The more the French increased terrorism and repression, the more Algerians resisted colonial domination. During the night of November 1, 1954, a handful of armed nationalists confronted French soldiers. Considering this event as a dangerous condition and labeling the repressive measures of the colonial government as "the struggle against terrorism," the colonial government expanded the legal powers of the army and the police. According to Raphaëlle Branche $(2004,135)$, "In the spring of 1955, the government succeeded in passing a law declaring a state of emergency that expanded the powers of the civil and military authorities in Algeria. The state of emergency contravened the law on two fronts, both by allowing exceptional police measures and by extending military authority." Consequently, the French army targeted both combatants and civilians and "two acts of violence grew exponentially: summary executions and internment in camps" (Branche 2004, 138).

Hostages were murdered and noncombatant citizens were collectively punished: "The execution of hostages owed its genesis to colonial law, which assigned collective responsibility in the case of certain infractions, and authorized collective punishments, including forced labor. This principle was enforced in the spring of 1955: if an attack took place, the nearest village was considered collectively responsible. The reprisals that ensued might include executing hostages" (Banche 2004, 139). Tortures, beatings, and rapes were also used as forms of colonial terrorism: "Torture sessions began with the systematic stripping of the victim. One method of torture was rarely used alone. It was more often combined with one of five separate tactics: beatings, hanging by the feet or hands, water torture, torture by electric shock, and rape" (Branche 2004, 140). Rape was a theatre of violence in Algeria; gang rapes were often common. Rape as an act of terrorism was intended to impose psychological destruction on Algerian society. As Branche $(2004,141)$ states,

[Type text] 
"This particular act of violence struck a well-aimed blow at one of Algerian society's foundations: the virginity or 'purity' of women. It also attacked the manhood of Algerian men, which relied upon their ability to defend their women."

As the Algerian national struggle was intensified, the French colonial government increased colonial terrorism although it failed to crush the will of the Algerian people. So Algeria achieved it political independence in 1962. Similarly, Africans in former Portuguese colonies faced waves of terrorism during slavery, colonialism, and liberation struggle. According to David Birmingham (2006, viii), "In Angola and the neighboring territories, labor recruitment took forms of compulsion, coercion, and conscription that were distressing similar to the practices utilized by pre-colonial slave traders. Violence as a means of driving men and women to work ceaselessly for foreigners continued to be prevalent throughout most of the colonial period."

After the Scramble for Africa, Portugal intensified its policies of effective control and pacification to prevent loses of its colonies to its rival imperial and internal resistance forces. Between 1870 and 1905, the Portuguese effectively colonized the interior of Angola and Mozambique through series of wars and terrorism (Smith 1985, 493-520). According to Bruce Vandervort $(1998,146)$, "The Portuguese imperial renaissance of the 1890s, spurred on by national indignation at the country's humiliation at the hands of her imperial rivals, meant war for the peoples who inhabited the African lands over which Portugal claimed sovereignty. In Angola, beginning in the 1880s, Portuguese columns made increasingly vigorous efforts to break out of the coastal regions and on to the central plateau, to penetrate the northern rain forests and to bring the arid lands of the far south under effective control. In Guinea-Bissau ... Portuguese military pressure on the interior increased . . . Mozambique; however, was the major arena of Portuguese colonial warfare."

There were various peoples and independent kingdoms that refused to recognize the colonial power of Portugal and resisted to pay taxes and to work on colonial projects and plantations. The Portuguese army and its African mercenaries used warfare and terrorism to break the will of these Africans. Vandervort $(1998,148)$ notes that the Portuguese used "military force to crush the various, largely independent peoples of the interior, and to transform them into obedient contributors of the head tax and productive labourers on the plantations of the chartered companies that were being created to help develop [and exploit] Mozambique" and other colonies. The Portuguese engaged in what they called the wars of pacification, which caused thousands of deaths and exiles. With increased resistance in Angola and Mozambique, the Portuguese colonial forces terrorized the indigenous peoples, destroying cultures, institutions, and communities, denied wells during drought, killed or exiled their leaders (Herbert 2003, 29-38).

After the mid-1950s different nationalist groups that later formed nationalist movements emerged and demanded national independence. To respond to these conditions, the colonial government and its army intensified terrorism to prevent them from fighting for their rights. "No child grew up in Angola without risking a daily encounter with violence,"

\footnotetext{
${ }^{24}$ MPLA was formed on April 4, 1961, PAIGC on January 23, 1963, and FRELIMO on September 25, 1964. Revolutionary nationalists of the Movimiento Popular de Libertação de Angola (MPLA), the Partido Africano da Independencia de Guiné e Cabo Verde (PAIGC), and the Frente de Libertaçă de Moçambique (FRELIMO) were terrorized and brutalized. According to Birmingham (1999, 133), "On 4 February 1961 the young people of the city of Luanda experienced terror. Some of them, led by their elders, had hot-headedly tried to storm the prison in order to liberate leaders of the incipient nationalist movement in the city. They had failed and the white [Type text]
} 
Birmingham (1999, 133-134) writes, "police violence, gang violence, domestic violence, conscripted violence, exiled violence, the violence of permanent fear permeating a whole society and a whole generation." As soon as the MPLA started the Angolan liberation struggle in September 1962, thousands of refugees moved to neighboring countries (Humbaraci and Muchnik 1974, 123). The condition in Mozambique was not different. The uprisings of the sugar-cane plantation workers and dock strike in 1963 met with bloody reprisals, arrests and deaths (Humbaraci and Muchnik 1974, 146-147).

With the intensification of the national struggle under the leadership of FRELIMO, most nationalists were terrorized and brutalized by the Portuguese forces. Furthermore, Western European and American financial aid contributed to the suppression of these Africans. As Birmingham (1999: 234) asserts, "The more the West [supported] the forces of minority white domination in Africa, the more Angola, Guinea Bissau and Mozambique [would] be different from those countries who had their independences granted-sometimes virtually on a silver platters." Let us now explain how the Dutch and English colonial settlers imposed terrorism and apartheid in South Africa.

The first Dutch settlers arrived in the Cape peninsula ${ }^{25}$ in 1652 and started to dispossess the homelands of the Africans and to kill or enslave them. The Dutch East India Company occupied the Cape peninsula under the leadership of Jan van Riebeeck, built a refreshment station for Dutch vessels traveling between the Netherlands and the East Indies, and supplied with fruit, vegetables, and meat (den Berghe 1970, 13-14; Thompson 2001, 32). In 1662, the Cape of Good Hope emerged as a complex and racially stratified society. ${ }^{26}$ Although the Dutch settlers initially established fairly cordial relationship with the Khoikhoi

population launched a revenge vendetta of extreme virulence. The police allowed expatriate and settlers to have weapons and to enter the suburbs and slums in search of potential nationalist sympathizers. An informal white militia led a savage vendetta. . . . Adolescents were dragged from their beds and murdered in the streets." Similarly, on June 16, 1960, the governor of the Cabo Delgado district ordered "the deliberate massacre of at least a thousand Africans" because they petitioned for their independence (Humbaraci and Muchnik 1974, 146).

${ }^{25}$ Bartholomeu Dias sailed two little vessels in 1486 from Portugal in search of an ocean road to India; Dias named the Cape of Storms, but King John II named it the Cape of Good Hope. English, Dutch, and French ships followed the Portuguese to India after a long interval (Theal 1969, 10).

${ }^{26}$ There were three factors for this: "First, the company released some of its employees from their contracts and gave them land with the status of 'free burghers.' Second, the company landed slaves at the Cape and set them to work under Dutch supervision on creating the basic infrastructure for the colony - a fort, a jetty, roads, orchards, vegetable gardens, and arable fields. Third, as the Dutch settlement expanded slowly but surely from the shore of Table Bay and engrossed and enclosed land for cultivation, it did so at the expense of the local pastoralists, who had the option of withdrawing from the fresh water resources and the rich pastures of the northern part of the Cape peninsula or remaining there as servants or clients of the Dutch" (Thompson 2001, 33). The company brought more settlers from the Netherlands; these settlers included "a few orphan girls and 156 men, women, and children of French origin-Huguenots who had fled to the Netherlands after 1685" (Thompson 2001, 35) who faced a religious persecution in France. Some political exiles and prisoners were also dumped in the peninsula (den Berghe 1970, 14). As the need for labor arose, more slaves were brought from Dahomey (now Benin), Angola, Mozambique, Madagascar, Indonesia, India, and Ceylon (Sir Lanka). The first ship of slaves was imported in 1658. "Though subsequent shipments, the number of slaves began to outnumber that of Whites by the first half of the eighteenth century," Pierre van den Berghe $(1970,14)$ writes, "and the Western Cape became a firmly entrenched slave society until 1834, when slavery was abolished throughout the British Empire." In addition, the enslavement of the indigenous Africans in the Cape and its surrounding contributed in increasing the number of the slave population. 
and acquired sheep and cattle in exchange of European goods, they gradually started to use violence to dispossess their lands and forcing them into slavery. The settlers began to have upper hand on the Khoikhoi and other indigenous peoples because of the superiority of their organization, weaponry, and the divisions among the indigenous peoples. The Dutch settlements expanded from generation to generation. According to Leonard Thompson (2001, 38), "Gaining confidence from their defeat of the peninsula people, the settlers became increasingly brutal. They branded, thrashed, and chained Khoikhoi"

The settlers first destroyed the sovereignty of the Khoikhoi by expropriating their economic resources and by destroying their leadership, institutions, and culture and reducing them to the status of slaves or coerced workers (Freund 1984, 55-56). The Pastoralist Boers "most relied on Hottentots [Khoikhois] and, later, Bantu serfs, who cost nothing but little food, and whose destitution forced them into the service of the Boers after the latter had deprived them their land" (den Berghe 1970, 23). Initially, the Dutch East India Company expropriated their economic resources such as land and "livestock-their most valued possessions: the records of the company show that between 1662 and 1713 it received 14,363 cattle and 32,808 sheep from the Khoikhoi. Their fragile political system had collapsed, and the chiefs had become pathetic clients of the company. In the 1680s, individuals and families had begun to detach themselves from their society and serve burghers as shepherds and cattle-herds" (Thompson 2001, 38). Furthermore, the European diseases such as smallpox finally annihilated the Koikhoi, pastoral society.

The settlers also invaded, terrorized, destroyed, and used the remaining population of San, hunter-gathers society, as slaves or coerced workers. Then they continued to attack, colonize, and destroy African farming communities. Although the Bantu-speakers Africans such as Xhosa and Zulu who were mixed farmers seriously resisted the incursion of Europeans to their homelands, they were also defeated and dominated after many centuries. As we shall see below, because of the essence of their social formations, the occupationally differentiated Africans, namely Koikhoi, San, and Bantu speaking Africans ${ }^{27}$ (such as the Zulu, Ndebele, and Sotho) had varied experiences with their European enemies. Relatively speaking, it was more difficult to attack, colonize, and destroy the African farming communities than the pastoral and hunting-gathering communities. The regime of the Dutch East Indian Company and white colonial settlers and their diseases annihilated the indigenous African peoples between 1652 and 1795 .

The Dutch colony was expanded on different directions without any competition until 1795 (Theal 1969 [1894], 96-111), when England captured the Cape from the Dutch. As the Dutch settlers known as Trekboers "moved deeper and deeper into the interior and edged more and more of the indigenous herders out of control of the land, they drew many of them into their service ... For the right to continue to live on the land and to pasture a few livestock of their own, they herded the invaders' cattle and sheep, they drove their ox wagons, and they did their domestic chores. Trekboers also made use of people from the indigenous hunting and gathering communities. Commandos exterminated adult huntergatherers but made a point of capturing children, and before they disbanded they distributed the children as well as the cattle booty among themselves" (Thompson 2001, 49). The Boers

\footnotetext{
${ }^{27}$ The peoples who were living in South Africa were the hunter-gatherers San, the pastoralist Khoikhoi, and the mixed farmers Bantu-speakers. Europeans gave them derogatory names and called the hunter-gatherers Bushmen, the pastoralists Hottentots, and the mixed farmers Kaffirs.
}

[Type text] 
viewed the San as vermin and, for instance, their commando killed 503 and captured 239 in 1774, and killed 2503 and took as prisoners 669 between 1786 and 1795 (de Berghe 1970, 24).

After 1795, both the Dutch and English colonial settlers continued the policy of terrorizing and annihilating the indigenous peoples of South Africa. ${ }^{28}$ Those indigenous Africans who lived in the eastern part of southern Africa were terrorized and colonized during the early $19^{\text {th }}$ centuries: "In 1811 and 1812, in a campaign that set the precedent for the piecemeal conquest of all the black farming people of Southern Africa, British regular troops, assisted by colonial commandos and Khoikhoi units, ruthlessly expelled the Xhosa inhabitants from the land through to the Fish River, burning crops and villages and making off with thousands of head of cattle" (Thompson 2001, 54-55). After occupying the Cape peninsula, like the Dutch the British settlers started to terrorize and colonize the frontier political and farming communities. John Cradock, the British military governor of the Cape of Good Hope, appointed John Graham as Commissioner for the frontier and announced that "security and good order cannot prevail if any description of persons are suffered to remain within British territory who are not subject to the regulations of the State, or who either live uncontrolled, or obey the mandates of any other authority" (quoted in Magubane 1996, 44).

Graham outlined his plan to annihilate the leadership and communities such as Xhosa; he explained that "the expediency of destroying the Kaffir [Bantu speakers] Kraals, laying waste their gardens and fields and in fact totally removing any object that could hold out their chiefs an inducement to revisit the regained territory" (quoted in Magubane 1996, 45). He started the frontier war and terrorism of 1811-12. According to Bernard M. Magubane (1996, 45), this "was total war because it did away with the distinction between military and civil categories. It was total war because it affected all levels of individual and community life: political, economic, psycho-social, and military." Graham instructed the British soldiers to kill all Xhosa males, but his soldiers killed both men and women. Furthermore, the British forces got rid of the Xhosas by depriving them of the means of substance such as corn and millet and cattle.

During the frontier war and terrorism "20, 000 Africans were driven from their lands across the Fisher River, and a double line of block-houses (garrisoned with troops and civilians) was built, behind which quitrent farms of 4,000 acres each were offered to the colonial settlers" (Magubane 1996, 46). After they were removed from their homelands, the surviving Xhosas became coerced workers for the British settlers. With the discovery of diamonds and gold in 1867 and 1884 respectively in Kimberly and Witwatersrand, the British colonial government intensified colonial terrorism. ${ }^{29}$ Those Africans who survived were

\footnotetext{
${ }^{28}$ The Boers used war and terrorism to destroy various African peoples: "The cattle raids and territorial encroachment of the Boers led to an endless series of frontier wars . . . These are known in South African history as the 'Hottentot Wars' of 1659 and 1673, the 'Kaffir Wars' of 1779, 1789, 1799, 1812, 1818, 1835, 1846 , and 1850, and the 'Basuto Wars' of 1851, 1858, 1865, and 1880, not to mention almost countless small skirmishes, cattle raids, reprisals, and 'punitive expeditions' which, in the case of the Boer commandos against the Bushmen [San], took the character of genocide" (de Berghe 1970, 23).

${ }^{29}$ The British "launched a wave of aggressive wars that would decide once and for all that Britain and its Cape Colony were the ultimate owner of these newly found riches of South Africa .... In 1873 the British made war against the Hlubi; and in 1877 against the Gcaleka and the Pedi; and against the Ngqika, Thembu, Pondo, Griqua, and Rolong in 1878. The Zulus were next in 1879, the Sotho in 1880, the Ndebele in 1893, and the Afrikaner republics in 1899. The Cape absorbed the Transkei and its peoples during the period 1879-94. Prior to that, Britain had annexed Basutoland in 1868, Griqualand West in 1871, the South African Republic in 1877, [Type text]
} 
disarmed and settled on reservations; they were forced to be coerced laborers in mining and e farming industries. Despite the fact that the southern African kingdoms and societies initially established friendly commercial relationship with Europeans, the Europeans wanted to own African lands by violating the norms of society: "White farmers . . claimed to own the land they had been permitted to use, whereas the idea that a person could have property rights in land did not exist in African culture" (Thompson 2001, 71).

The Africans started to realize that these Europeans were dangerous to them and their interests. The Europeans settlers used the cleavage in African societies, firearms, and the Africans "lacked the equipment to capture fortified positions or laagers composed of circles of wagons, and when Africans resorted to guerrilla tactics the invaders forced them into submission by attacking their food supplies. Time after time, Afrikaner [Dutch settler] commandos and British regiment brought Africans to their knees by systematically destroying their homes, crops, and grain reserves, seizing their livestock, and turning their women and children into refugees" (Thompson 2001, 72). Both the Dutch (Afrikaners/Boers) and the British contested to own African resources such as land, cattle, labor, and minerals.

However, in 1870 "African kingdoms, Afrikaner republics and British colonies coexisted in a rough equilibrium of power, but pursuing widely differing social and economic goals. Although most Africans lived in largely self-sufficient agrarian societies, few were untouched by the coming of the merchant and the missionary" (Marks 1985, 359). In the Scramble for South Africa between years 1877 and 1895, South Africa emerged as a "white man's country" (Schreuder 1980, 4-9). According to D. M. Schreuder (1980, 9), "What mattered most of all was that the local balance of power had tilted permanently against the authority of the African political communities in favour of the Europeans; that the peculiar modern political-economy of the region had been formed; and that the settlement patterns particularly those of territorial segregation and the 'right to the land' - were ultimately decided." How did all these happen?

Particularly it was not easy for the Dutch and English settlers to terrorize and dominate the Zulus; "for most people in Europe and America, recognition of the valor of African fighting men begins and ends with the Zulus" (Vadervort 1998, 102). Moving to the Zululand, the Afrikaners attacked the Zulus in December 1838. Despite the fact that the Zulus were well organized under their able king Dingaan, Shaka's successor, their invading enemies massacred them. According to Vadervort (1998, 109), "It was a rude shock for the Zulus, who fell by the thousands to Boer elephant guns on the banks of the Ncome River in Natal .... ' $[\mathrm{T}]$ he mass of ... Zulus was hemmed between the banks, and the press grew intolerable as the regiments strove to reach the wagons .... It was only necessary to fire and reload and fire again at the black mass that seethed out of the smoke.' More than 3,000 Zulus died ... without killing a single Boer." Consequently, the Boers colonized Natal and declared it a republic; however, the British took Natal from Boer in 1846.

The Boers left the republic and moved to the Boer republics in the Orange Free State and the Transvaal. Now the British had to face the Zulus. Although the Zulus challenged the British at many war fronts, they finally lost "the war because their traditional military strategy of head-on engagement in the long run could not prevail against the breech-loading

Zululand in 1887, Matabeleland in 1894, and the Afrikaner republics in 1900. The Zulu rebellion in 1906, in which nearly 4,000 Africans were killed, marked the last stage in 250 years of armed struggle by the traditional societies against white invaders" (Magubane 1996, 53).

[Type text] 
rifle" (Vadervort 1998, 111). The British also used the divide and conquer strategy to destroy the power of the Zulus: "The final defeat of the Zulu people and the absorption of Zululand into the British South African Empire, stemmed from the British ability to intensify, in the post-conflict period, divisions within the Zulu hierarchy that had surfaced before and during the war" (Vadervort 1988, 111). More than the war with British, the ensuing bloody civil war between Zulu factions destroyed the Zulu kingdom in the 1880s. With the Zulu rebellion of 1906, the British increased its violence; more than 3,380 people were murdered or hanged, thousands imprisoned; hundreds of leaders were annihilated (Herbert 2003, 85-93).

Although the Dutch and English colonialists defeated these African farming communities, expropriated their lands and livestock, and forced some of them into coerced labor, they could not disintegrate these communities because they were conditioned to the diseases brought from Europe, their numerical superiority to the settlers, "their economy was more complex, their social networks were far more resilient, and their political systems were far more durable" than the hunter-gatherers and pastoral communities (Thompson 2001, 72). Despite the fact that "the white settlers were few in number, their polities were frail, and their pockets of settlement were bordered by autonomous African polities," "the white impact intensified dramatically as a result of the discovery of the world's greatest deposits of diamonds, soon to be followed by gold, in the heart of southern Africa" (Thompson 2001, 72). According to Thompson $(2001,109)$, "Great Britain, unchallenged by European rivals, dominated the external trade of the region. In spite of the ambition of their creators, the Afrikaner states were inexorably part of the informal British empire."

Both the British army and militia and Afrikaner commandos dominated Africans through colonial terrorism and transformed Southern Africa in the last decades of the $19^{\text {th }}$ century. Finally, the British army defeated the Afrikaner republics between 1899 and 1902, and formed the Union of South Africa in 1910. As D. M. Schreuder $(1980,19)$ argues, "The overall result was that British involvement in South Africa was many-layered and deep; it began with the trade and naval interest of the Indian Ocean, and extended on through the dockyards and strategic harbours, into the settler societies about them, and then on into the hinterland of the region, as a dimension of an overall concern for an inviolate supremacy around, and in, Southern Africa." However, all white groups, farmers, businesspeople, traders, missionaries, government officials, and others had a common interest in terrorizing Africans, appropriating their lands and minerals, using their coerced labor, and dominating their markets despite the contradictions existed among them.

At the end, all African groups were brought under white domination in Southern Africa for almost four centuries. The Dutch and English colonizers justified their colonial terrorism and the establishment the racist political economy and structures in the discourses of racial superiority, Christianity, and European civilization. In these complex processes, the violent racist state and apartheid society were born in South Africa ${ }^{30}$ Furthermore, the British forces colonized Lesotho in 1844, Botswana in 1896, and Swaziland in 1906. Similarly, in

\footnotetext{
${ }^{30}$ In order to maintain white racial hegemony and the domination and exploitation of Africans and others, the racist state developed notorious and complex rules and laws. "An open opposition to apartheid was labeled 'communism,' a serious criminal offence. The Suppression of Communism Act (1950) empowered the Minister of Justice to 'ban' organizations and individuals defined as communist. When banned, a person was prevented from associating with others or even talking with two or more people at the same time. To be accused of promoting a communist organization was to risk imprisonment for up to ten years. The law designed to silence opposition to the apartheid government" (Falola 2002, 202).
}

[Type text] 
1890, the British expedition force consisting of 184 English and Afrikaner whites and 300 black mercenaries violently occupied Southern Rhodesia (now Zimbabwe) and Northern Rhodesia in 1891 under the leadership of Cecil Rhodes and the company called the South Africa Company; these forces settled there and confiscated the lands and cattle of the Ndebele and Shona peoples (Turok and Maxey 1985, 248-249).

Overall, the process of terrorizing and colonizing Africans was intensified by the strategy known as the European Scramble for Africa between 1884 and 1900; this colonial project exposed almost all of African peoples to European domination and forced them to lose their sovereignties and economic resources (Sanderson 1985, 96-158), facilitated the destruction of independent leadership and societies, and caused millions of deaths through various forms of violence and diseases. The European colonial powers wanted to expropriate African lands, minerals, and other economic resources, and to use free or cheap African coerced labor to exploit these resources and to feed their industrial and market needs (Sanderson 1985). They used commerce, religion, and terrorism to acquire what they wanted from Africans. A few African leaders initially "misunderstood the objectives of the colonial enterprise" (Falola 2002, 182) and signed the so-called treaties with the European powers; "African leaders signed documents to show that they surrendered their power and agreed to promote trade and accept other conditions. There is no evidence that many African chiefs understood the contents of the treaties" (Falola 2002, 179).

Of course, most African leaders and societies did not sign treaties with the European powers and resisted European colonialism to retain their sovereignties and protect their lands and other economic resources, institutions, and cultures. Of course, some of those African leaders who signed treaties also resisted European colonialism after they realized the intentions of the European powers. The Europeans had the power of technology, organizational capacity, and resources to build and use professional armies devoted to fulltime war and terrorism; they had the ability to recruit large armies of African troops who were ready to fight on their behalf in Africa and to provide information on Africa. According to Toyin Falola $(2002,183)$, "The Europeans relied on improved firearms. Africans used bows, arrows, and muzzle-loading guns (such as Dane guns), which had to be loaded slowly. The European armies in the area of the partition relied on breech-loaders, rifles that could fire at the rate of about ten rounds per minute. Whereas the European armies had adequate modern guns (the Maxim and Gatling), their African rivals lacked access to them." Using professional armies and modern guns, ${ }^{31}$ the Europeans intensified ruthless wars and terrorism on resisting African societies and forced them to accept European colonialism by the threat of violence. The European power also gathered information from explorers, missionaries, enslaved Africans, and merchants (Falola 2002, 182; Vandervort 1998, 29).

As we have already mentioned, France colonized some African coastal areas in the $17^{\text {th }}$ century and Algeria in the early $19^{\text {th }}$ century. Although France formed the French West Africa in 1895 , since the $17^{\text {th }}$ century it controlled St. Louis, Rufisque, Gorée, and Dakar in Senegal, Grand Bassam and Assini in Côte d'Ivoire, and in a small coastal area in Dahomey (now Benin). The French Federation of West Africa consisted of Senegal, Côte d'Ivoire, Niger, Benin, French Sudan (now Mali), French Guinea, Mauritania, and Tog (after WW II). France also established its colony in East Africa; it colonized Obock, an important

\footnotetext{
${ }^{31}$ According to Bruce Vandervort $(1998,49)$, "It was thought that machine guns might be useful for terrorizing Africans ... and a few were sent out to the colonies, where they were instrumental in putting down the mass rebellions."
}

[Type text] 
commercial center on the Red Sea in 1862. Furthermore, it occupied the Ambado and Djibouti areas between 1885 and 1892; Djibouti became the capital of French Somaliland in 1896. France also occupied Tunisia in 1881 and part of Morocco in the late $19^{\text {th }}$ century. After establishing their first foothold for about two hundred years at a trading post called St. Louis at the mouth of the Senegal River, "French traders had seen the Senegal as a highway into the interior of West Africa, to exotic place like Timbuktu, which they believed to be the source of a rich trade in ivory, gems and gold. But disease and powerful African opponents made expansion into the interior an extremely difficult process, and for a long time French commerce in West Africa was largely confined to the trade in human beings" (Vandervort 1998, 70).

The French merchants used St. Louis and the island of Goree in the $17^{\text {th }}$ and $18^{\text {th }}$ centuries for slave trade and for sending slaves to the French sugar plantations in the West Indies. After the 1850s, France started to expand its colonial expansion into the interior of Senegal; it started to fight against the Moors and Tukolors. It intensified the war of colonial expansion and terrorism between 1870 and 1905 (Person 1985, 208-256; Hargreaves 1985, 257-297). The French army raided villages, burned homes, destroyed crops, and driven off herds. Despite the fact that the Tukolors who were related to the Fulani tried their best to resist French colonialism under the leadership al-Hajji Umar, they were defeated because of the firepower and the greater mobility of the French army (Vandervolt 1998, 79). Ahmadu Seku, the eldest son and chosen successor of al-Hajji Umar tried to prevent the destruction of the Tukolor Empire. However, in 1889, Segu, the capital city of Ahmadu was captured; then the conquest of fabled Timbuktu followed. Then France turned to fight against Samori Toure $^{32}$ (1830-1900), one of the greatest leaders in West Africa.

His military genius and political acumen could not save his country from French colonialism, and he was captured in 1898 and died in $1890 .{ }^{33}$ Furthermore, France colonized Wadai (now the Republic of Chad) between 1909 and 1912. Wadai was suffering from the destruction of slavery during the arrival of the French. The French installed their puppet chiefs such as Acyl and others, destroyed those leaders that opposed to French colonialism, and ruled Chad until the mid-1960s. In French West Africa, the Tuareg revolted in Southern Sahara from 1916 to 1917. In Niger, they were terrorized, killed, and ruthlessly repressed. According to Herbert $(2003,1201)$, "In their conflict with the French, the Tuareg lost not only their traditional way of life but also a large proportion of their ruling elite. In addition many of the surviving rebels fled to villages in French Mali and British Nigeria." Similarly, the pacification of the Ivory Coast involved war, terrorism, and the destruction of leadership and society. When in the homeland of Baoulé, guerrilla warfare continued between 1898 and 1900the French increased terrorism and repression (Suret-Canale 1964, 96).

The French colonial government gave full power for its police to collect taxes from people who were resisting colonial rules: "tax ... gathered at the cost of villages burnt down, chiefs and natives killed in large numbers, heads of chiefs put up on poles, the imposition of fines" (quoted in Suret-Canale 1964, 99). In North Africa, France expanded its colonial

\footnotetext{
${ }^{32} \mathrm{He}$ was called the Bonaparte of the Sudan. He was born in the Guinea Highlands from Mandingo people. Samori introduced a commercial revolution in West Africa.

${ }^{33}$ Vandervort $(1998,135)$ asserts that "if Samori had not had to fight the French, there is every indication that he had the organizing genius and sufficient control of his people to have created a state responsive to the needs of the approaching twentieth century."
}

[Type text] 
occupation from Algeria to Tunisia in 1881 and Morocco in 1906 (Ganiage1985, 159-207). The last Moroccan guerrilla fighters resisted French colonialism until 1934. The 'pacification' of the fierce Berber fighters of Morocco by the French started between 1903 and 1904. In 1912, France established its protectorate on Morocco. In 1904 the French and Spanish colonial governments decided bilaterally that the northern coastal region would be regarded as a Spanish zone of influence, ${ }^{34}$ and the eastern Morocco would be under French influence.

Furthermore, France colonized Madagascar in 1896 through ruthlessly terrorizing various indigenous peoples in the island (Deschamps 1985, 521-538). During the turn of the $20^{\text {th }}$ century, France used five measures to eliminate the possibility of resistance. It completely disarmed the people, arrested and deported leaders, imposed payment of retroactive taxes and war fine, imposed coerced labor and annual tax payment, and destructed camps and settlements in villages (Suret-Canale 1964, 100-102). Since the people revolted against these measures, the French forces used terrorism and systematic political repression to impose them (Coquery-Vidrovitch 1985, 298-315). The police toured the villages, attacked communities, and ravaged their crops to force them to pay taxes. As Hochschild $(1998,280)$ expounds, "In France's equatorial African territories . . . the amount of rubber-bearing land was far less than what Leopold controlled, but the rape was just as brutal. Almost allexploitable land was divided among concession companies. Forced labor, hostages, slave chains, starving porters, burned villages, paramilitary companies 'sentries,' and the chicotte [whipping] were the order of the day."

In the French Congo to celebrate Bastille Day two white men "had exploded a stick of dynamite in a black prisoner's rectum" (Hochschild 1998, 280-281). Millions of Africans were decimated while constructing roads and railways. "In the 1920s, construction of a new railway through French territory bypassing the big Congo River rapids cost the lives of an estimated twenty thousand forced laborers," Hochschild $(1998,281)$ writes, "far more than had died building and later rebuilding, Leopold's railway nearby." Similarly, Great Britain established its colonies through war and terrorism. As we have discussed above its role in Southern Africa, let us explore how it occupied and dominated other parts of Africa. Britain colonized Aden between 1839 and 1840 "for the strategic necessity of assuring imperial communication of India" (Thompson and Adloff 1968, 5). In 1848, one British officer hailed "that true weapon the bayonet, which never yet failed to bring success to the British soldier" (quoted in V. G. Kiernan 1982, 123). When the Turko-Egyptian forces were weakened and

\footnotetext{
${ }^{34}$ Spain occupied the garrison coastal cities of Ceuta and Melilla since the $16^{\text {th }}$ century and part of Morocco known as Western Sahara since the beginning of the 20th century and Spanish Guinea in West Africa. When Spain attempted to develop mining areas in the Rif Mountain, the Moors, Arabs and Berbers resisted. Consequently, Spain sent its expeditionary force between 1911 and 1912 to effectively control northern and western Morocco. This force destroyed the building and crops, orchards, and killed unknown numbers of people (Herbert 2003, 165). Both Italy and Spain were minor European colonial powers. Italy occupied Libya between 1911 and 1912 by expelling the Turks, and occupied Abyssinia between 1935 and 1941. According to Bruce Vandervort (1998, 186), “The Italians were still trying to 'pacify' the Libyan hinterland when they entered the First World War in 1915; the 'pacification' of Libya would only be completed under the Fascist regime in 1932." Later it also partitioned Somaliland with France, Britain, and Abyssinia and occupied Italian Somaliland and curved Eritrea in the Horn of Africa.
} 
abandoned garrison towns on the Somali coast, Harar, and eastern Oromia, "European imperialism became more active, and the three western powers already involved in the Horn of Africa strove to fill the vacuum. The British occupied the ports of Zeila and Berbera, the French made treaties with the sultans of Tadjoura and Gobaad for cession of their territory, and Italians asserted claims to the Assab area" (Thompson and Adloff 1968, 7).

Italy occupied Libya 1911 and Massawa in 1885. Britain's colonialism of Somaliland was not limited to the coast but extended to the hinterland later called British Somaliland. The British was interested in Somaliland because of its potential in mineral resources and to trade in frankincense, skins, meat, and other products. Somalia was partitioned among four countries, France taking the north, Britain the middle, Italy the south, and Abyssinia the west. "It was the British who came in for most of the rough work," V. G. Kiernan $(1982,81)$ notes, "having to take on the celebrated 'Mad Mullah', another of those enigmatic personalities - he was a gifted writer as well as partisan - who led the rearguard action of the old Islamic world against European intrusion, but were at the same time harbingers of something new, national unification." The resistance of Somalis to British colonialism under the leadership of Mohammed ibn Abdullah Hassan who the British called the "Mad Mullah" brought terrorism and war on Somalis. The warrior Mullah attacked those who collaborated with the enemy, collected arms, organized men into military, and preached a holy war against the colonial occupying forces (Herbert 2003, 57).

The British sent several expeditionary forces against this "political and military leader of the highest caliber" and his followers, terrorized and killed thousands of people, burned villages, raped women, and looted resources (Herbert 2003, 57-67). They also mobilized 5000 Abyssinian/Ethiopian soldiers against the Somalis under the leadership Gabri. The British attack that started in 1901 against the Somali resistance forces ended in 1921, when the British and the Abyssinian armies defeated the followers of the Mullah. After colonizing Egypt in 1882, Britain occupied the areas now called Kenya 1896, Uganda, the island of Zanzibar, and Sudan in 1899. By declaring protectorate over present-day Kenya, Uganda, and island of Zanzibar, Britain established British East Africa. The indigenous peoples of these areas resisted British colonialism when the colonial office intensified land expropriation, taxation, and recruitment of coerced labor; they attacked white officials, settlers, and traders (Herbert 2003, 78).

To crush this resistance, the British started to raid and terrorize these peoples. One of the indigenous peoples that defied the Pax Britannica was the Nandi who lived in the hills northeast of Lake Victoria. The British colonial office established the Nandi Field Force in 1905 to terrorize, defeat and destroy the Nandi community. The force killed 1,117 Nandis, looted 16,000 cattle, 36,000 sheep and goat, burned 5000 huts and grain stores, and forcefully moved the surviving population to reservations (Herbert 2003, 80). In 1900 one official expressed that "the England of today, intoxicated with militarism, blinded by arrogance, indifferent to truth and justice" (quoted in V.G. Kiernan 1982, 178). Like the Nandi, the Embu and Kikuyu peoples revolted in Kenya because their economic resources particularly their lands were given to white settlers. The Kikuyu formed the Land and Freedom guerrilla army that the British called Mau-Mau; in 1963, when Kenya achieved its independence 11,500 Kikuyu were murdered when only 32 white settlers were killed (Herbert 2003, 85). 
Similarly, refusing to pay taxes, providing labor and forced relocation, the Giriama ${ }^{35}$ rebelled in 1914 against British colonialism in Kenya: "The colonial administration had attempted to introduce taxes and to relocate people according to the requirements of the labour market, in order to boost economic conditions along the coast" (Herbert 2003, 219). The British forces destroyed the fort of Kaya Fungo and raped women that sparked the fire of rebellion. At the end of the year, the Giriama were terrorized and cowed by the British expeditionary forces and 150 of them killed, 5,000 of their huts burned, and 3,000 of their goats confiscated (Herbert 2003, 220). British colonialism was expanding to other parts of Africa. When Britain was sending its colonial army from Egypt to occupy Sudan, there was a politico-religious movement known as Mahdia that was struggling against Turko-Egyptian colonial domination in Sudan. The religious leader who called himself the Mahdi led this movement. ${ }^{36}$ One of the Mahdi's best generals, Abu Anja, defeated the Anglo-Egyptian army of 8,500 men at the battle Shaykan in November 1883 (Vandervort 1998, 168). When Britain sent her famous general, Charles George Gordon in 1884 to extricate some of her men from Sudan, the Mahdi army captured and beheaded him. After a decade, Britain attempted to occupy the Sudan under the leadership of Major-General Horatio Herbert Kitchener.

Madhi died in 1885 and replaced by his chosen successor and his second-in command, the Khalifa Abdullahi. Using superior weapons such as gunboats, Kitchener defeated the Madhist army at Firket on June 7, 1896. At the battle of Omduruman in 1898, the British army using their superior weapons mowed down the followers of the Mahdi, killed the Khalifa in 1899 and ended the Mahdia Movement. As Vandervort $(1998,177)$ notes, "The many thousands of Mahdists dying and wounded on the battlefield received no aid from the British, who simply turned their backs and marched away. This gives an indication of the depth of feeling in the ranks about the death of Gordon." Of course, the pacification of different parts of Sudan continued through war and terrorism. For example, when the leader of Darfur in Western Sudan refused to pay taxes, the Anglo-Egyptian government sent its expeditionary forces and killed 261 and seriously wounded 96 peoples and disbanded about 4,000 soldiers (Herbert 2003, 188-195).

The British had already started to establish their colonies in West Africa and in the early $19^{\text {th }}$ century. The Ashanti kingdom between 1823 and 1824 and between 1873 and 1874 challenged this colonial expansion. Bruce Vandervort $(1998,84)$ asserts, "Britain found herself locked in a dispute on the Gold Coast of West Africa with the kingdom of Ashanti, one of the great empires of pre-colonial Africa. The subsequent Anglo-Ashanti war was Britain's first major conflict in the rain forests of tropical Africa." The founding of European trading posts on the shores of the Gold Coast (now Ghana) contributed to the wealth and power of the Ashanti kingdom. This African kingdom was involved in the criminal trade of slavery. According to Vandervort $(1998,85)$, "By the 1680 s . . . slaves accounted for some 75 percent of regional exports. Ashanti military activity during this period was geared closely

\footnotetext{
${ }^{35}$ The Giriama migrated in the $17^{\text {th }}$ century from Somaliland to present-day Kenya and built a fortress called Kaya Fungo in the district of Kilifi South, northwest of Mombasa (Herbert 2003, 219).

${ }^{36}$ According to Vandervort $(1998,166)$, "it was widely believed in the Sudan that, with the dawn of the new century, God would send a Mahdi or saviour, to end oppression by the Egyptians, who had re-established control over the Sudan in the 1830s, and to purify the Muslim faith of secular excrescences imposed upon it by the westernized Egyptians and Ottoman Turks. The man who stepped forth to declare himself the Expected Mahdi, Muhammad Ahmad bin Abdullah, was 40 years old, the son of a Nile boat builder and already a holy man of some repute in the valley of the White Nile."
}

[Type text] 
to seizing slaves for sale to the Europeans, who had begun setting up trading posts like Cape Coast Castle or Accra along the Gold Coast." Gold was an important commodity, too.

Despite the fact that the British claimed to own Cape Coast Castle, Ashanti asserted sovereignty on the coastal area. Since the British did not want to recognize Ashanti sovereignty, the relationship between the kingdom and the British officials was broken in 1823. In 1824, an Ashanti army killed General Sir Charles McCarthy and beheaded him; the defeat of the British army led to "the greatest failure in the history of the British occupation of the Gold Coast" (quoted in Vandervort 1998, 85). In 1871, when the British purchased the littoral of the Gold Coast from the Netherlands, the Ashanti kingdom claimed it as part of its empire. Vandervort $(1998,87)$ notes that the Dutch recognized Ashanti's sovereignty over its enclave of Elmina "whose African inhabitants were loyal subjects of Kumasi, was a vital Ashanti outlet to the sea, where Ashanti merchants could trade directly with foreign suppliers of guns, gunpowder and iron rods (which were cut up to make bullets). In order to preserve the status quo in the former Dutch ports, King Kofi had demanded British recognition of Ashanti sovereignty over the coastal enclaves and payment of annual rent."

The refusal to accept the demand of the Ashanti Kingdom led to war between 1873 and 1874. This time mainly because of its artillery and breech-loaders, the British force defeated the Ashanti army and left "Heaps of dead and wounded." 37 The British army had continued to terrorize the Ashantis since they continued to resist British occupation. "Invaded by an army composed largely of African troops from Nigeria and Central Africa," Vandervort $(1998,101)$ writes, "with a sprinkling of Sikhs, the Ashanti gave the British 'their last as well as the hardest battle the latter had ever fought in their longstanding attempts to control and finally subjugate Ashanti.", The British also gradually established their colonial administration in Southern Nigeria and expanded to the north. ${ }^{38}$ Lugard declared war on Northern Nigeria known as Hausaland particularly on Kano and Sokoto kingdoms. ${ }^{39}$ As the people resisted British colonialism in Hausaland, the British force increased its brutality and terrorism. For example, when Dan Makafo, a religious leader, rebelled in March 1906 in Sokoto, the British mowed down 2,000 men and tried the rebel leader; "some other prisoners were killed and their heads cut off and placed on spikes; the village of Satiru was razed to the

\footnotetext{
37 "The number of Ashanti causalities will never be known, but British estimates of as many as 3-4,000 dead and perhaps twice as many wounded and missing do not seem wide of the mark. Beyond this and the destruction of the capital city, the military defeat threatened to destroy the Ashanti Empire, as provinces and tributary states began to declare their independence of Kumasi. As it was, an independent Ashanti would survive for only 12 years, at which point another British army would invade the heartland of the empire, this time bent on occupation and the absorption of Ashanti into the Gold Coast Protectorate" (Vandervort 1998, 98-100).

${ }^{38}$ According to Vandervort 1998, 189), "The year 1898 saw a monumental changing of the guard in Nigeria, as chartered company rule came to an end with the purchase by the British government of the rights and properties of the Royal Niger Company of Sir George Taubman Goldie for $£ 850,000$. So passed into the hands of the state not only Southern Nigeria but also the company's somewhat specious claims to Northern Nigeria . . . . [The company's troops] and men eventually would be incorporated into the new West African Frontier Force (WAFF), created in $1897 \ldots$ to vie with the French for control of the hinterlands of the Gold Coast and the Central Sudan. The WAFF would become the instrument of imperial conquest of the man now appointed to lead it, the old Africa hand and bête noire of the French, Frederick Lugard."

${ }^{39}$ Starting in 1900 the British control was extended to northern states and war was declared on Kano on February 3, 1903 in which more than 300 men were killed (Herbert 2003, 50-51). Similarly Sokoto was attacked on March 14, 1903 in which about 100 men were killed; on May 13, 1903, the British killed between 250 and 300 Fulani-Hausa (Herbert 2003, 51).
}

[Type text] 
ground" (Herbert 2003, 52). "The continuing legacy of colonial occupation is an artificial amalgam of some 250 [ethnonational groups] in 30 states," Herbert $(2003,56)$ writes, "Speaking some 400 languages, under a military government dominated by the northern Fulani-Hausa favoured by the British civilian and military authorities."

The impacts of colonial terrorism were more devastating in the colonial territories of Germany and Belgium. In 1884, Germany proclaimed a protectorate and started its conquest of Southwest Africa (now Namibia) in 1885 with the arrival of imperial commissioner, Heinrich Göring. Southwest Africa belonged to the Herero, the Nama, and the Damara peoples. ${ }^{40}$ In 1893, 200 German troops staged a surprise attack on the Nama town of Hornkranz because Hendrick Witbooi, the leader of Nama refused to recognize German authority. But Witbooi submitted after 18 months of resistance after some of his people were murdered. The German colonial governor, Theodor Leutwein, had a plan for the indigenous peoples; his prediction was that " 15 years from now, there will not be much left for the natives" (quoted in Kiernan 2007, 381). Herbert (2003, 117) describes that "from 1904 to 1907 first the Herero and later the Nama fought an outstandingly brave, initially vicarious, but ultimately tragic battle against their German overlords. The spark that ignited the fire was the action of the Germans in desecrating the old burial place of the Herero chiefs at Okahandja by cutting down the sacred trees and turning the place into a vegetable garden."

The Germans saw the indigenous peoples as inferior human beings, drove them from their lands, and destructed their leadership and their way of life (Vandervort 1998, 197). General Lothar von Trotha, the commander the German forces, proclaimed the following: "no war may be conducted humanely against nonhuman . . . It was and is my policy to use force with terrorism and even brutality. I shall annihilate the revolting [ethnonations] with rivers of blood and rivers of gold. Only after a complete uprooting will something emerge" (quoted in Kiernan 2007, 382). The German troops poisoned water holes to kill the indigenous peoples and their cattle; they also pushed the Hereo into the Omaheke Desert so that they would die of thirst. On August 11, 1904, the German troops "began 'indiscriminate killing of the wounded, male prisoners, women and children.' Herero causalities quickly reached 5,000 killed and 20,000 wounded . . German units seized the water holes, forcing the surviving 50,000 Herero to head into the Omaheke Desert. The pursuing German troops massacred almost everyone they found, including women and children, and poisoned the water holes in the desert ... By the end of September, the Germans had 'effectively destroyed most of the Herero people", (Kiernan 2007, 383).

Jan-Bart Gewald (2004, 59-60) expounds, "The German settlers and soldiers carried out a shoot-to-kill policy, conducted extrajudicial killings, established concentration camps, employed forced labor, and in at least two cases established death camps." While resisting German colonialism, the Herero were exposed to "a typhus outbreak, a locust plague, and drought killed 10,000 Herero, and a rinderpest epidemic wiped out 80 percent of their cattle herds" (Kiernan 2007, 381). General Trotha issued an 'Extermination Order" on October 2, 1904 by proclaiming the following: "The Herero people must leave this land. If it does not, I will force it to do so by using the great gun [artillery]. Within the German border every male Herero, armed or unarmed, with or without cattle, will be shot to death. I shall no longer

\footnotetext{
${ }^{40}$ The Herero were cattle herders and they were about 75,000 when the Germans arrived in Southwest Africa. The Nama, a linguistic group of Khoi-San were numbered possibly 20,000. The Damara who were partly enslaved by Herero and Nama numbered about 30,000 (see Kiernan 2007, 381).
}

[Type text] 
receive women or children, but will drive them back to their people or have them shot at. These are my words to the Herero people" (quoted in Kiernan 2007, 383).

The Germans annihilated the indigenous peoples, destroyed their institutions, and took over their homelands. ${ }^{41}$ According to Ben Kiernan $(2007,386)$, "The destruction of the Herero proved to be the opening genocide of the twentieth century. Among the three main Southwest African ethnic groups, totaling 125,000 people before 1904, German repression took approximately 80,000 lives in three years, at a cost of 676 German dead, 907 wounded, and 97 missing." The German soldiers and settlers engaged in "extreme acts of violence and cruelty, and they sought, shot, beat, hanged, starved, and raped Herero men, women, and children . . . no fewer than 80 percent of the Herero had lost their lives. Those who remained in Namibia, primarily women and children, survived in concentration camps as forced laborers employed on state, military, and civilian projects" (Gewald 2004, 60). Using terrorism and genocide, German imperialism crushed these indigenous peoples: "When a census was taken in 1911, only half of the Nama estimated a decade before $(9,800$ out of $20,000)$ and less than a quarter of the Herero $(15,000$ out 80,000$)$ were found to have survived the war. Those that did had little choice but to become labourers on Europeanowned farms" (Herbert 2003, 129).

In 1898, the Germans established their East African colony (now Tanzania, Rwanda, and Burundi). The movement known as the Maji Maji Rebellion emerged in Tanzania between 1905 and 1906. This rebellion was initiated by the Ngion, a branch of Zulu nation, in the west and the Mattumbi in the east. According to Herbert $(2003,130)$, "The Ngoni had a particular grudge against the Germans due to the execution of some of their chiefs, and the Matumbi had suffered constant demands for forced labour in the cotton fields, which had badly affected their own subsistence farming." The Germans reacted excessively and brutally as in Southwest Africa; their "starvation policy resulted in the death of an estimated 100,000 Africans and the south of the colony became a vast smoking ash heap" (Herbert 2003, 132). Three German columns went to the rebellious areas in 1905 and burned villages, destroyed crops, and caught and hanged rebellious leaders (Vadervort 1998 1998, 203). The Germans annihilated thousands of indigenous people through war, terrorism, and famine. Some areas "once densely inhabited, reverted to their natural state and in due course became the largest game park in the world" (Herbert 2003, 135). From 250, 000 to 300, 000 people were decimated by starvation as a result of the Maji Maji Rebellion (Vadervort 1998, 203).

Similarly, in West Africa Germany occupied Togo and Cameroon and practiced similar policies. Two Cameroon kings, King Bell of Douala and King Akwa "agreed to give up their sovereignty [their lands at the mouth of the Cameroon River] under a treaty signed on July 1884 with the German Imperial Consul-General for the west coast Africa" (Herbert 2003, 136). However, the Germans started to carry out the occupation of the entire country moving into the north and interior between 1895 and 1907. Since the indigenous peoples of Cameroon did not make any concession with the Germany, they opposed colonialism and fiercely resisted. Leaders such as Zubeiru organized militia, but his force was defeated and slaughtered (Herbert 2003, 138). Consequently, the Fulani power in north Cameroon was defeated and leaders were executed or jailed or exiled, and the Germans established their

\footnotetext{
${ }^{41}$ When 30,000 of them had perished within a week, 1,000 of Hereros crossed the desert and reached British Bechuanaland (now Botswana), 2,000 of them escaped north to Ovamboland or South to Namaland, 17,000 of them were rounded by German forces for work as slave laborers; 7,000 of them "died like flies" on coastal towns such as Swakopmund in prison, and by hard work, famine, and murder (Kiernan 2007, 385).
}

[Type text] 
rigid control (Herbert 2003, 138). The Germans executed King Manga Bell and King Joja and others accusing them for inciting rebellions. Through terrorism, brutality, and harshness, the German army reduced the remaining population into coerced workers for German traders and planters.

German terrorism was similar to that of Belgium in the Congo. Between 1890 and 1910, the worst of the bloodshed occurred in the Congo under the Belgium colonial administration. The Belgium colonial terrorism caused "one of the great mass killings of recent history;" it was also "the vilest scramble for loot that ever disfigured the history of human conscience" (quoted in Hochschild 1998, 3-4). King Leopold II initiated his colonization of the Congo through his agent Henry Stanley, ${ }^{42}$ an American explorer, ${ }^{43}$ between 1880 and 1884. Stanley laid "claim to the territory through a series of outposts, ${ }^{44}$ most of them on the lower Congo toward Atlantic," and prepared ways of establishing an efficient transportation system, military conquest, efficient administration, and commercial exploitation of what was to become the Congo Free State (Vandervort 1998, 136). With Belgian money and local labor, he constructed a railway from the Atlantic Coast to Kinshasa and established a fleet of steamboats to navigate on the Congo River. These measures enabled Leopold to effectively occupy the vast Congo region. According to Vandervort $(1998,137)$, in 1885 "A makeshift administration was established at Boma, near the mouth of the Congo, and an army, called the force Publique, ${ }^{45}$ created in 1886 to assist in the "effective occupation' of the king's vast domain."

\footnotetext{
${ }^{42}$ Stanley's expeditionary forces stole land from the indigenous peoples and engaged in terrorism by kidnapping women, children and men. These forces took hostage women and children, burned villages, shot the peoples until the leaders provided them food. Stanley and his men used a variety of trick to steal native lands, caused a wave of death and destruction by being "excessively cruel to . . . prisoners, condemning them ... to the chain gang"" and by putting ox-chains "into the necks of the prisoners and producing sores about which the flies circle, aggravating the running wound," by "kidnapping African women and using them as concubine,' and by "shooting villagers, sometimes to capture their women, sometimes to intimidate the survivors into working as forced laborers, and sometimes for sport" (Hochschild 1998, 110-111).

${ }^{43}$ When Henry Morton Stanley formerly known as John Rowlands was sent to Africa in the spring of 1871 to find David Livingstone by James Gordon Bennett, the publisher of New York Herlad, and found him after eight months of traveling in Africa. When King Leopold II, the king of Belgium, heard in 1872 that Stanley found Livingstone, he showed a great interest in Africa. Livingstone was the embodiment of the European impulse to Africa to seek raw materials, to expand Christian evangelism and to know more about Africa. He was a missionary, physician, explorer and adventurer who began to travel across Africa in the early 1940s. Although he was considered "the first to cross the continent from coast to Coast ... the first recorded crossing of central Africa, unacknowledged by Stanley and almost all the other white explorers, had been made half a century earlier by two mulatto slave traders, Pedro Baptista and Anastasio José. Theirs was also the first round trip" (Hochschild 1998, 28).

${ }^{44}$ Stanley claimed that "he was able to buy land for a station by paying some chiefs with 'an ample supply of fine clothes, flunkey coats, and tinsel-braided uniforms, with a rich assortment of divers' marketable wares ... not omitting a couple of bottles of gin" (Hochschild 1998, 63). He manipulated more than 450 Congo basin chiefs to sign so-called treaties to give Leopold a trading monopoly and their land for almost nothing. According to Hochschild $(1998,72)$, "The very word treaty is a euphemism, for many chiefs had no idea what they were signing. Few had seen the written word before, and they were being asked to mark their X's to documents in a foreign language and in legalese. The idea of a treaty of friendship between two clans or villages was familiar; the idea of signing over one's land to someone on the other side of the ocean was inconceivable." The treaty was intended to give a legal veneer for terrorism that would be used to transfer land ownership to the king and to reduce the native to coerced laborers.

${ }^{45}$ Leopold used African mercenaries between 1879 and 1884. In 1888, he organized formally the Force Publique, an army for his new state (more than 19,000). Divide into small garrison - several dozen black [Type text]
} 
The Force Publique secured food and labor force, such as porters, through terrorism and other forms of violence to exploit and make the Congo profitable. First of all, the colonial state wanted porters "to collect ivory, set up new posts, put down a rebellion . . . to carry everything from machine-gun ammunition to all that red wine and pâté. These tens of thousands of porters were usually paid for their work, if only sometimes the food necessary to keep them going, but most of them were conscripts. Even children were put to work: one observer noted seven-to nine-year olds each carrying a load of twenty-two pounds" (Hochschild 1998, 119). As Vandervort $(1998,145)$ notes, "The biggest problem faced by the companies and state officials involved in developing the Congo was the securing of labour. Since the Africans did not seem eager to volunteer their services, the king's administrators in Boma stepped in to help. They instituted a system of forced labour, under which Africans were rounded up by the Force Publique and turned over to special African overseers called sentilles who enforced work quotas with shotguns and rhinoceros-hide whips."

Another way of recruiting labor was by imposing heavy taxes in cash, and when the Africans failed to pay in cash demanding them to pay in kind such as natural rubber, palm nuts, or ivory. According to Vandervort (1998, 145), "If the Africans resisted, as some did, they received a visit from the Force Publique, which often burned the villages, killed women and children, and took away the men as slaves. Africans who failed to meet their quotas-and the quotas were often set unrealistically high-were whipped or, in some highly-publicized cases, had their hands lopped off." $\quad$ Leopold made a number of royal decrees from Brussels; the first decree was made in 1885 to declare the existence of the Conge Free State and to declare, "that all 'vacant land' was the property of the state. There was no definition of what made land vacant" (Hochschild 1998, 117). In the first decree he claimed the ownership of all land and its resources and products. He also made another decrees to lease the vacant and non-vacant land to private companies for long periods. ${ }^{46}$ Leopold deployed troops and government officials as well as investment funds to dominate the business (1985, 330-333). His forces terrorized and coerced the Africans to gather ivory and wild rubber while claiming that he "was not to make a profit, but to rescue these benighted people from their indolence" (Hochschild 1998, 118).

soldiers under one or two white officers. All commissioned officers and some sergeants of the Force Publique whites; all the ordinary soldiers were black. One volunteered soldier said that he preferred "to be with the hunters rather than with the hunted" (quoted in Hochschild 1998, 127).

46 As Hochschild $(1998,117)$ states, "These concession companies had shareholders-largely, though not entirely Belgian - and interlocking directorates that included many high Congo state officials. But in each of them the state-which in effect meant Leopold himself — usually kept 50 percent of the shares. In setting up this structure, Leopold was like the manager of a venture capital syndicate today. He had essentially found a way to attract other people's capital to his investment schemes while he retained half of the proceeds. In the end, what with various taxes and fees the companies paid the state, it came to more than half." 
In the early $1890 \mathrm{~s}$, Leopold made ivory gathering and seizing his main goal. ${ }^{47}$ In addition to ivory, wild rubber became the main source of revenue after the late 1890s from the Congo. ${ }^{48}$ As the need for more labor increased to collect rubber, the labor recruitment system was more militarized. ${ }^{49}$ Force Publique officers took hostages of women, children, elders or chiefs. ${ }^{50}$ The hostage taking, the cutting of noses and ears, and the severing of hands were deliberate policies. "If a village refused to submit to the rubber regime, state or company troops or their allies sometimes shot everyone in sight, so that nearby villages would get the message .... As the rubber terror spread throughout the rain forest, [terror] branded people with memories that remained raw for the rest of their lives" (Hochschild 1998, 165). Whipping also imposed terror by the chicotte. ${ }^{51}$ The authorities sanctioned terror and permitted each capita, an African foreman to administer the bulk of Chicotte to torture bodies of other Africans. The administration of Chicotte "created a class of foremen from among the conquered, like the kapos in the Nazi concentration camps and the predurki, or trusties, in the Soviet gulag. Just as terrorizing people is part of conquest, so is forcing someone else to administer the terror" (Hochschild 1998, 122-123).

Between 1904 and 1905, Leopold II sent his Force Publique to the north of Belgian Congo to colonize Zandeland and to attack and destroy the Azande King Gbudwe and King Djabbir of eastern Congo. Both the English forces from Sudan and the Force Publique gave final blow and sealed Gbudwe's fate (Herbert 2003, 45). Both Britain and Belgium destroyed the kingdom Zandeland by killing its king and establishing their respective colonial rule. The Force Publique decimated the Azande and their "corpses were placed in twos and threes in shallow holes and covered with earth, while the women "wailed and shrieked" (quoted in Herbert 2003, 45). In 1910 Anglo-Sudanese troops forced the Froce Publique to leave Zandeland. The depopulation of the Africans under Belgium rule was caused by murder, starvation, disease, and a plummeting birth rate. Force Publique soldiers or Rubber Company "sentries" often killed thousands of Africans. Missionaries, members of the Force publique

\footnotetext{
${ }^{47}$ As Hochschild $(1998,118)$, states, "Congo state officials and their African auxiliaries swept through the country on ivory raids, shooting elephants, buying tusks from villagers for a pittance, or simply confiscating them. Congo peoples had been hunting elephants for centuries, but now they were forbidden to sell or deliver ivory to anyone other than an agent of Leopold. A draconian refinement of the ivory-gathering method, which set the pattern for much that was to come, was a commission structure the king imposed in 1890, whereby his agents in the field got a cut of the ivory's market value-but on a sliding scale. For ivory purchased in Africa at eight francs per kilo, an agent received 6 percent of the vastly higher European market price. But the commission climbed, in stages, to 10 percent for ivory bought at four francs per kilo. The European agents thus had a powerful incentive to force Africans-if necessary, at gunpoint - to accept extremely low prices."

48 "The profits came swiftly because, transportation costs aside, harvesting wild rubber required no cultivation, no fertilizer, and no capital investment in expensive equipment. It required only labor" (Hochschild 1998, 159-

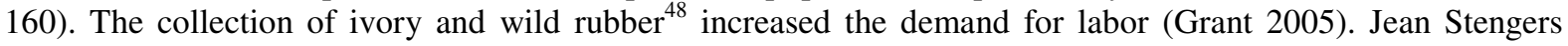
$(1985,319)$ testifies the increase in rubber production and export: "In 1890 the Congo exported only 100 metric tons of rubber; in 1896, exports reached 1,300 metric tons: in 1898, 2,000 metric tons; and in 1901, 6,000 metric tons. This last figure corresponded approximately to a tenth of the world production of rubber."

${ }^{49}$ Instructions how to take hostages to collect ivory and rubber were written in Manuel du Voyageur et du Résident au Congo and Practical Questions; every government agent and officer was given the manual.

50 "Every state or company post in the rubber areas had a stockade for hostages. If you were a male villager, resisting the order to gather rubber could mean death for your wife" (Hochschild 1998, 161).

${ }^{51}$ The chicotte was "whip of raw, sun-dried hippopotamus hide, cut into a long sharp-edged cork-screw strip. Usually the chicotte was applied to the victim's bare buttocks. Its blow would leave permanent scars; more than twenty-five strokes could mean unconsciousness; and a hundred or more-not an uncommon punishment-were often fatal" (Hochschild 1998, 120).
}

[Type text] 
and other witnesses documented about cutting of hands and private parts of men, killing of children and women, hanging of people, mass murder, cutting of heads. Starvation, exhaustion, and exposure decimated hundreds of thousands of people. ${ }^{52}$

Hunger, starvation and diseases killed more than did bullets; Europeans brought diseases for which Africans did not build up immunities. All these factors resulted in the decrease of the birth rate. Several sources testify that during the Leopold period and its immediate aftermath, the Congo Free State lost almost half of its population, which was approximately ten million. The death of King Leopold in 1910 brought change and continuity in the Belgium colonial system. The king died a billionaire. Belgium wanted to continue to extract more wealth form the Conge Free State. It took over the Congo and replaced wild rubber with cultivated rubber and introduced a new method of forcing people through taxes: "The imposition of a heavy head tax forced people to go to work on the plantations or in harvesting cotton, palm oil, and other products - and proved an effective means of continuing to collect some wild rubber as well" (Hochschild 1998, 278). The system of forced labor remained intact; ${ }^{53}$ the Africans were also mined copper, gold, and tin. Because of the lack safety conditions several thousands of mineworkers died; for instance, "in the copper mines and smelters of Katanga, five thousand workers died between 1911 and 1918" (Hochschild 1998, 279).

The demand for uranium and rubber increased the suffering of Africans: "With the start of the Second World War, the legal maximum for forced labor in the Congo was increased to 120 days per man per year. More than 80 percent of the uranium in the Hiroshima and Nagasaki bombs came from the heavily guarded Congo mine of Shinkolobwe. The Allies also wanted ever more rubber for the tires of hundreds of thousands of military trucks, Jeeps, and warplanes." Some of the rubber came from the Congo's new plantations of cultivated rubber trees. But in the villages Africans were forced to go into the rain forest, sometimes for weeks at a time, to search for wild vines once again (Hochschild 1998, 279). In 1960, the Congo achieved its flag independence. ${ }^{54}$ Generally speaking, there was no any part of Africa that did not face colonial terrorism. Even the peoples who were brought under the neo-colonial states of Abyssinia (now Ethiopia) and Liberia had suffered from colonial terrorism like other Africans. The European powers used African auxiliaries and collaborators in merchandizing and owing some Africans and directly and indirectly colonizing the entire African continent. According to John Lonsdale (1985, 723), "Alien white commanders were generally accompanied by a swarm of African auxiliaries seeking to profit by a raid on neighbours, whether they were vengeful tributaries . . . competitors of pasture . . . or levies provided by locally dominant rulers who seized the chance to convert their sphere of influence into a sub-imperialism."

\footnotetext{
${ }^{52}$ As Hochschild $(1998,229)$ testifies, "As they fled these expeditions, villagers sometimes abandoned small children for fear that their cries would give away their hiding places. As a result, many children starved. A small proportion of the population, lucky enough to live near the Congo's borders, escaped from the country."

53"'It was legal for mine management to use the chicotte, and at the gold mines of Moto, on the Upper Uele River, records show that 26,579 lashes were administered in the first half of 1920 alone. This figure was equal to eight lashes per full-time African worker" (Hochschild 1998, 278-279).

${ }^{54}$ Since the West did not like its firebrand revolutionary leader, Patrice Lumumba, who was elected as Prime minister, they assassinated him. With the support of the West Mobutu Sese Soko, a former sergeant-major in the Force Publique who also had played a role in murdering the prime minister took power and ruled the Congo with iron hand until 1997.
}

[Type text] 
With the support of England, France, Italy, Abyssinia/Ethiopia created its own empire by colonizing and terrorizing peoples such as Oromos, Somalis, and Sidamas. Because of their Christian ideology and the willingness to collaborate with European imperialist powers, successive Amhara-Tigrayan of Ethiopia rulers received access to European technology, weapons, administrative and military expertise, and other skills needed for the construction of the neo-colonial state and the Ethiopian Empire (Holcomb and Ibssa, 1990; Jalata 2005). According to Martial De Salviac, "With equal arms, the Abyssinia [would] never [conquer] an inch of land. With the power of firearms imported from Europe, Menelik [Abyssinian warlord] began a murderous revenge" (De Salviac 2005, 6). The main reason for the Abyssinian/Ethiopian colonial expansion was to obtain commodities such as gold, ivory, coffee, musk, hides and skins, slaves, cattle, and land. This state engaged in terrorism and committed genocide on peoples such as Oromos to expropriate these materials. The Ethiopian colonial terrorism and genocide that started during the last decades of the $19^{\text {th }}$ century still continue in the $21_{\text {st }}$ century. Ethiopia, former Abyssinia, terrorized and committed genocide on the Oromo people during the Scramble for Africa with the help of European imperial powers and the modern weapons they received from them.

During Ethiopian colonial expansion, Oromia (the Oromo country), "the charming Oromo land, [would] be ploughed by the iron and the fire; flooded with blood and the orgy of pillage" (De Salviac 2005 [1901], 349). Calling this event as "the theatre of a great massacre," Martial De Salviac $(2005,349)$ states, "The conduct of Abyssinian armies invading a land is simply barbaric. They contrive a sudden irruption, more often at night. At daybreak, the fire begins; surprised men in the huts or in the fields are three quarter massacred and horribly mutilated; the women and the children and many men are reduced to captivity; the soldiers lead the frightened herds toward the camp, take away the grain and the flour which they load on the shoulders of their prisoners spurred on by blows of the whip, destroy the harvest, then, glutted with booty and intoxicated with blood, go to walk a bit further from the devastation. That is what they call 'civilizing a land.'" The Oromo oral story also testifies that Ethiopians destroyed and looted the resources of Oromia, and committed genocide on the Oromo people through massacre, slavery, depopulation, cutting hands, famine, and diseases during and after the colonization of Oromia.

The colonization of Oromia involved human tragedy and destruction: "The Abyssinian, in bloody raids, operated by surprise, mowed down without pity, in the country of the Oromo population, a mournful harvest of slaves for which the Muslims were thirsty and whom they bought at very high price. An Oromo child [boy] would cost up to 800 francs in Cairo; an Oromo girl would well be worth two thousand francs in Constantinople" (De Salviac 2005, p. 28). According to Alexander Bulatovich (2000: 68-69), "The dreadful annihilation of more than half of the population during the conquest took away from the Gallas [Oromos] all possibilities of thinking about any sort of uprising . . . Without a doubt, the Galla, with their least five million population, occupying the best land, all speaking one language, could represent a tremendous force if united." The destruction of Oromo lives, institutions, and Oromian natural beauty were aspects of Ethiopian colonial terrorism. The surviving Oromos who used to enjoy an egalitarian democracy known as the gadaa system 
(Oromo democracy) were forced to face state terrorism, political repression, and an impoverished life. ${ }^{55}$

Ethiopian colonialists also destroyed Oromo natural resources and the beauty of Oromia. Oromia was "an oasis luxuriant with large trees" and known for its "opulent and dark greenery used to shoot up from the soil" (De Salviac 2005, 21-22). De Salviac (2005, 21) also notes that "the greenery and the shade delight the eyes all over and give the landscape richness and a variety which make it like a garden without boundary. Healthful climate, uniform and temperate, fertility of the soil, beauty of the inhabitants, the security in which their houses seem to be situated, makes one dream of remaining in such a beautiful country" The Abyssinian colonialists devastated "the forests billing from it the laths for their houses and [made] campfires or firewood for their dwellings . . . [They were] the great destructors of trees, others [accused] them of exercising their barbarity against the forests for the sole pleasure of ravaging" (De Salviac 2005, 20). Bulatovich (2005, 21) applied to Oromia the phrase "flowing in milk and honey" to indicate its abundant wealth in cattle and honey. The Ethiopian colonial state gradually established settler colonialism in Oromia and between 1868 and 1900, when Oromia, the Oromo country, was effectively colonized by Abyssinia, the Menelik forces reduced the Oromo population from 10 to 5 million; war, slavery, famine, and disease contributed to the destruction of the Oromo people (Bulatovich 2000).

As the Amhara-dominated successive regimes engaged in terrorism and genocide and exploited the resources of Oromos, Afars, Somalis, Sidamas, Annuaks, and others, since 1991 the Tigrayan-led government is engages in similar practices to suppress the national movements of these indigenous peoples in order to continue domination and exploitation. The successive regimes of Menelik, Haile Selassie, Mengistu, and Meles have been racist and dictatorial and have continuously pursued destructive and violent policies that have denied the people subsistence, protection, and development. As France, England, and Italy helped Ethiopia to colonize Oromia, successive hegemonic powers, namely England, former USSR and the US have supported and maintained successive Ethiopian governments. Similarly, with the help of the United States, Americo-Liberians colonized and terrorized the indigenous Liberians (Gershoni 1985; Sundiata 2003). The indigenous Liberians are divided into three linguistic groups known as the Mande, the Kru, and the Mel.

The first African Americans settled in what is today called Liberia in 1822; they settled in Cape Mesurado where local peoples did not yet form a strong political organization to defend themselves (Gershoni 1985, 5). The American Colonization Society (ACS) that was mainly organized by powerful whites to remove freed Blacks from the United States planned, organized, and settled these Black immigrants (Tyler-McGaw, 2007). According to Claude A. Clegg III (2004, 112), "Despite the denials of ACS officials, Liberia meant slavery and abolition, pawing and free labor, and a range of practices in between. In perpetual tension, the colony was a patchwork of all these things, exhibiting stark contradictions and timeless continuities." The ACS was transformed into "an agent for the federal government, taking

\footnotetext{
55 Alexander Bulatovich $(2000,68)$ explains about the gadaa administration and notes that "the peaceful free way of life, which could have become the ideal for philosophers and writers of the eighteenth century, if they had known it, was completely changed. Their peaceful way of life is broken; freedom is lost; and the independent, freedom loving Gallas find themselves under the severe authority of the Abyssinian conquerors."
}

[Type text] 
care of the transportation and colonization of all blacks. Between 1822 and 1867, the ACS brought 18,858 immigrants to the coast of West Africa" (Gershoni 1985, 8).

In 1824, with the help of the United States the ACS developed an administrative framework for a colony named Liberia, its capital Monrovia, naming after one of the presidents of the United States. This political structure emerged as the Republic of Liberia in June 1847. Liberia "operated more or less as an American protectorate" (Sundiata 2003, 10). Unfortunately, Americo-Liberians brought with them racist beliefs and practices that they learned in the United States ${ }^{56}$; they propagated the idea of spreading Christianity and Western civilization (Beyan 2005): "Imbued with feelings of superiority, they treated the indigenous population with contempt, even those Africans who did convert to Christianity. AmericoLiberians took great care to guard their distinctiveness by erecting social and economic barriers between themselves and the Africans" (Gershoni 1985, 22). Americo-Liberians established the Liberian Frontier Force (LFF), which was commanded and trained by U.S. Army officers; this force terrorized and established a military rule in the hinterland of Liberia. $^{57}$

Americo-Liberians established a colonial administrative system on the Liberian hinterland, and imposed their authority through war and terrorism: "The reign of terror, exploitation, and humiliation which characterized the rule of two of Liberia's more notorious commissioners . . . eventually pushed the northern chiefdoms into an all-out revolt" (Gershoni 1985, 88). The Liberian government imposed taxes and introduced coerced labor. The Liberian government agreed in 1914 with the Spanish colonial government in Spanish Guinea to export coerced laborers by receiving $£ 5$ per head (Sundiata 2003, 80-81). Recruiting the forced labor force involved various forms of violence. The violent overthrow the government dominated by Americao-Liberians did not bring peace to this troubled country, and war and terrorism continued until the early $21^{\text {st }}$ century (Moran 2006). So in Ethiopia and Liberia, colonial terrorism was practiced within the context of the modernizing project of global imperialism.

\section{Conclusion}

The European colonial powers merchandized and owned some Africans as commodities for almost three centuries, and completed the colonization of the entire continent in the late $19^{\text {th }}$ century to rob African resources, to dispossess African lands, and to terrorize and coerce Africans to freely or cheaply work for them. These processes of dehumanization and colonization were practiced through different forms of violence that destroyed African leadership, cultures, and societies. Through the practices of terrorism and genocide the European countries dominated the African political economies, enriched their countries and companies, and brought Africa under the domination of the European-dominated racialized capitalist world system. According to Adam Hochschild (1998, 301), "History lies heavy on

\footnotetext{
${ }^{56}$ The indigenous Africans were disfranchised, and it was only in 1946 that they were granted the right to vote. Even then the Liberian government "restricted the Africans and prevented them from automatically becoming Liberian citizens with equal rights. The Africans had to pass certain clearly defined criteria in order to receive these rights"(Gershoni 1985, 22).

${ }^{57}$ The indigenous Africans were terrorized and massacred because they resisted Americo-Liberian colonialism. According to Yekutiel Gershoni (1984, 44-45), "By August 1912, the LFF had been called upon to repress a revolt in Tappi, where it stayed until January 1913. Another contingent was employed from October 1912 to April 1913 in Rock Cess and River Cess. Between November 1914 and February 1915, yet another contingent fought in Gissi, and in Cape Palmas from April to June 1915; while in May 1915, there was fighting in Secomb and Planb."
}

[Type text] 
Africa; the long decades of colonialism, several hundred years of the Atlantic and Arab world slave trade, and-all to often ignored-countless centuries of indigenous slavery before that. From the colonial era, the major legacy Europe left to Africa was not democracy as it is practiced today in countries like England, France, and Belgium; it was authoritarian rule and plunder." Since the colonization, the entire Africans have been exposed to violence and lost their independent leadership and exposed to severe oppression and exploitation. Consequently, today the majority of Africans are suffering from absolute poverty, diseases, social and cultural crises, and powerlessness.

Learning from the experiences of colonial war and terrorism in the Americas, Africa, Australia and Asia, the European powers perfected their desire for killings and destruction of human beings. According to V. G. Kiernan (1982, 178), "For Europe at large expansion afforded an outlet to impulses of violence, and could relieve internal tensions, but there was always a chance that it might recoil and intensify them instead. If conquest was doing something to civilize the outer world, it was also doing something to barbarize Europe." The consequences of the First and Second World wars testify to this assertion. As far as the West continues to facilitate war and state terrorism on the rest of the world, the peoples in the West cannot achieve their true humanity and peace. One cannot maintain his or her humanity while dehumanizing other human beings. Furthermore, the reign of terror that has been imposed on the Rest by the West has produced in some corners of the Rest similar forces that engage in terrorism. Since these forces now share information and knowledge with the West as well as weapons, it is not easy to defeat and eradicate these forces without understanding, addressing, and solving all forms of terrorism.

Most modernist and Marxist scholars ignore these complex problems of Africans, and European countries have continued their systems of dominating and exploiting African peoples through the forms of leadership they created for Africa. As V. G. Kiernan (1982, 230) puts, "There are, after all, good reasons for prying into the past with the historian's telescope, and trying to see more clearly what happened, instead of being content with legend or fantasy. Of all reasons for an interest in the colonial wars [and terrorism] of modern times the best is that they are still going on, openly and disguised." Despite the fact that most African peoples have achieved flag independence since the mid- $20^{\text {th }}$ century, almost all Africans are still exposed to many forms violence, absolute poverty, and disease. We cannot critically understand all these problems without understanding the impacts of European colonial terrorism and war on various African peoples. Almost all of the African leaders of neocolonial states have followed the footsteps of their mentors, and they have engaged in dictatorship, violence, theft and robbery of the public resources; another predicament might be "a soldiery trained by the foreigner, dragons' teeth with harvest of wars and army coups" (K. G. Kiernan 1985, 227). Today most African countries are ruled by military terror under the patronage of the West. African leaders such as Kwame Nkrumah, Patrice Lumumba, and Amilcar Cabral who sought sovereignty for African peoples were overthrown or assassinated by Europe-American powers and their African collaborators.

\section{References}

Attaguile, Faith. 2004. "Book Review: On the Justice of Roosting Chickens" by Ward Churchill, http://www.kersplebedeb.com/mystuff/books/reviews/churchill_lip.html, accessed on June 16, 2009.

[Type text] 
Beyan, Amos T. 2005. African American Settlements in West Africa: John Brown Russwurm and the American Civilizing Efforts. New York: Palgrave.

Birmingham, David. 1999. Portugal and Africa. New York: St. Martin's Press, Inc. 2006. Empire in Africa: Angola and its Neighbors. Ohio: Ohio University Press.

Branche, Raphaël. 2004. "Torture and Other Violations of the Law by the French Army During the Algerian War." In Adam Jones (ed.), Genocide, War Crimes \& the West. London: Zed Books, pp. 134-145.

Boorstin, Daniel J. 1983. The Discoverers: A History of Man's Search to Know His World and Himself. New York.

Bulatovich, Alexander. 2000. Ethiopia through Russian Eyes: Country in Transition 1896-1898. Trans by Richard Seltzer (Lawrenceville: The Red Sea Press.

Clegg III, Claude A. 2004. The Price of Liberty: African Americans and the Making of Liberia. Chapel Hill: The University of North Carolina Press.

Coquery-Vidrovitch, Catherine. 1985. "French Congo and Gabon, 1886-1905." The Cambridge History of Africa, Volume 6, from 1870 to 1905, J. D. and R. Oliver (eds.), pp. 298-315. Cambridge. Cambridge University Press.

Davidson, Basil. 1961. The African Slave Trade: Pre-colonial History 1450-1850. Boston: The Atlantic Monthly Press. 1991. African Civilization Revisited. Trenton, NJ: Africa World Press. den Berghe, Pierre. 1970. South Africa: A Study in Conflict. Los Angeles: University of California Press.

De Salviac, Martial. 2005 [1901]. An Ancient People, Great African Nation, Trans. by Ayalew Kano, (East Lansing: Michigan).

Deschamps, Hubert. 1985. "Madagascar and France, 1870-1907." The Cambridge History of Africa, Volume 6, from 1870 to 1905, J. D. and R. Oliver (eds.), pp. 298-315. Cambridge. Cambridge University Press.

Falola, Toyin. 2002. Key Events in African History: A Reference Guide. Westport, Conn.: Greenwood Press.

Frank, Andre Gunder. 1978. World Accumulation, 1492-1789. New York: Monthly Review Press.

Frank, Andre Gunder. 1979. Dependent Accumulation and Underdevelopment. New York: Monthly Review Press.

Freund, Bill. 1984. The Making of Contemporary Africa. Bloomington: Indiana University Press.

Ganiage, Jean. 1985. "North Africa" Yvonne Brett (TR.). In J. D. Fage and Roland Oliver, (eds.), The Cambridge History of Africa, Volume 6. London: Cambridge University Press, pp.159-171.

Gewald, Jan-Bart. 2004. "Imperial Germany and the Herero of Southern Africa: Genocide and the Quest for Recompense," Genocide, War Crimes \& the West: History and Complicity, ed. by Adam Jones. London: Zed Books, pp. 59-77.

Goodwin, Jeff. 2006. "A Theory of Categorical Terrorism.” Social Forces 84: 20272046.

Grant, Kevin. 2005. A Civilised Savagery: Britain and the New Slaveries in Africa, 18841926. New York: Routledge.

Gershoni, Yekutiel. 1985. Black Colonialism: The Americo-Liberian Scramble for the

[Type text] 
Hinterland. Boulder: Westview Press.

Hargreaves, J. D. 1985. "Western Africa, 1886-1905." The Cambridge History of Africa, Volume 6, from 1870 to 1905, J. D. and R. Oliver (eds.), pp. 257-297. Cambridge. Cambridge University Press.

Herbert, Edwin. (2003). Small Wars and Skirmishes 1902-18. Nottingham, Great Britain: Foundry Books.

Hochschild, Adam. 1998. King Leopold's Ghost: A Story of Greed, Terror, and Heroism in Colonial Africa. New York: Houghton Mifflin Company.

Holcomb, Bonnie and Sisai Ibssa. 1990. The Invention of Ethiopia. Trenton, NJ: The Red Sea Press.

Humbaraci, Arslan and Nicole Muchnik. 1974. Portugal's African Wars. New York: The Third Press.

Jalata, Asafa. 2005. "State Terrorism and Globalization: The Cases of Ethiopia and Sudan, International Journal of Comparative Sociology, Vol. 46(1-2), pp. 79-102.

Kiernan, Ben. 2007. Blood and Soil: A World History of Genocide and Extermination from Sparta to Darfur. New Haven: Yale University Press.

Kiernan, V. G. 1982. From Conquest to Collapse: European Empires from 1815-1960. New York: Pantheon Books.

Lonsdale, John. 1985. "The European scramble and conquest in African history." The Cambridge History of Africa, Volume 6, from 1870 to 1905, J. D. and R. Oliver (eds.), pp. 680-766. Cambridge. Cambridge University Press.

Moran, Mary H. 2006. Liberia: The Violence of democracy. Philadelphia: University of Pennsylvania Press.

Magubane, Bernard. 1996. The Making of A Racist State: British Imperialism and the Union of South Africa, 1875-1910. Trenton, NJ: The Red Sea Press.

Marks, Shula. 1985. "Southern Africa, 1867-1886." The Cambridge History of Africa, Volume 6, from 1870 to 1905, J. D. and R. Oliver (eds.), pp. 359-421. Cambridge. Cambridge University Press.

Miller, Joseph C. 2002. "West Africa," The Atlantic Slave Trade. David Northrup, (Ed.), Second edition. Boston: Houghton Mifflin Company, pp. 45-51.

Nevinson, Henry W. 1906. A Modern Slavery. London: Haper \& Brothers.

Person, Yves. 1985. "West Africa, 1870-1886," Yvonne Brett (TR.). The Cambridge History of Africa, Volume 6, from 1870 to 1905, J. D. and R. Oliver (eds.), pp. 208-256. Cambridge. Cambridge University Press.

Vandervort, Bruce. 1998. Wars of Imperial Conquest in Africa, 1830-1914. Bloomington: Indiana University Press.

Rodney, Walter. 1972. How Europe Underdeveloped Africa. Washington, D.C.: Howard University Press.

Sanders, G.N. 1985. "The European partition of Africa: Origins and dynamics." The Cambridge History of Africa, Volume 6, from 1870 to 1905, J. D. and R. Oliver (eds.), pp. 96-158. Cambridge. Cambridge University Press.

Senechal de la Roche, Roberta. 1996. "Collective Violence as Social Control." Sociological Forum 11: 97-128.

Sloan, John W. 1984. "State Repression and Enforcement Terrorism in Latin America." Pp. 83-89 in The State as Terrorist, Michael Stohl and George A. Lopez, eds. Westport: Connecticut, Greenwood Press.

[Type text] 
Schreuder, D. M. 1980. The Scramble for Southern Africa, 1877-1895: The politics of Partition reappraised. Cambridge: Cambridge University Press.

Smith, Alan. 1985. “Angola and Mozambique, 1870-1905." The Cambridge History of Africa, Volume 6, from 1870 to 1905, J. D. and R. Oliver (eds.), pp. 493-520. Cambridge. Cambridge University Press.

Stengers, Jean. 1985. "King Leopold's Congo, 1886-1908." The Cambridge History of Africa, Volume 6, from 1870 to 1905, J. D. and R. Oliver (eds.), pp. 315-358. Cambridge. Cambridge University Press.

Suret-Canale, Jean. 1964. French Colonialism in Tropical Africa 1900-1945. New York: Pica Press.

Sundiata, Ibrahim. 2003. Brothers and Strangers: Black Zion, Black Slavery, 1914-1940. Durham: Duke University Press.

Theal, George M. 1969. South Africa. New York: Negro Universities Press

Thompson, Leonard. 2001. History of South Africa. New Heaven: Yale University Press. Thompson, V. and R. Adloff. 1968. Djibouti and the Horn of Africa. Stanford: Stanford University Press.

Thornton, John. 2002. "Warfare and Slavery," The Atlantic Slave Trade. David Northrup, (ed.), second edition. Boston: Houghton Mifflin Company, pp. 55-64.

Turok, Ben and Kees Maxey. 1985. "Sothern Africa in Crisis." In Political Economy of Contemporary Africa, Peter C. W. Gutkind and Immanuel Wallerstein, (eds.), second edition. London: Sage Publications, pp. 243-278.

Tyler-McGraw, Marie. 2007. An African Republic: Black \& White Virginians in the Making of Liberia. Chapel Hill: University of North Carolina Press.

Wallerstein, Immanuel. 1985. "The Three Stages of African Involvement in the WorldEconomy." In Political Economy of Contemporary Africa, Peter C. W. Gutkind and I. Wallerstein, (Eds.), second edition. London: Sage Publications, pp. 35-63.

Wallerstein, Immanuel. 1974. The Modern World-System. New York: Academic Press.

Wallerstein, Immanuel. 1980. The Modern World-System II: Mercantilism and the Consolidation of the European World-Economy, 1600-1750. New York: Academic Press.

Wilkinson, Paul. 1979. "Social Scientific Theory and Civil Violence.” Pp. 45-72 in Terrorism: Theory and Practice. Yonah Alexander, David Carlton, and Paul Wilkinson, eds. Boulder: Westview. 